\title{
Litogeoquímica do Complexo Campos Gerais e granitoides intrusivos, Arqueano/Paleoproterozoico, Brasil
}

\author{
Caio Vinícius Gabrig Turbay ${ }^{1 *}$, Cláudio de Morisson Valeriano ${ }^{2}$
}

\begin{abstract}
Resumo O Complexo Campos Gerais localiza-se próximo à borda sudoeste do Cráton do São Francisco Meridional, na Faixa Brasília. Seu conjunto litológico é composto por ortognaisses mesoarqueanos migmatizados (ortognaisses Campos Gerais e Mandembo). Esse conjunto é intrudido por granitoides neoarqeanos, além de granitos e tonalitos, provavelmente paleoproterozoicos. O Ortognaisse Campos Gerais apresenta estrutura migmatítica estromática, com mesossoma de composição tonalítica a monzogranítica, compondo uma suíte subalcalina, calcioalcalina, peraluminosa a metaluminosa. Idade modelo $\left(\mathrm{T}_{\mathrm{DM}}\right)$ encontrada foi de $3,2 \mathrm{Ga}\left(\boldsymbol{\varepsilon}_{\mathrm{Nd}}:-4,6\right)$. O Ortognaisse Mandembo compreende um conjunto predominantemente diatexítico nebulítico, de composição tonalítica a sienogranítica, subalcalina, calcioalcalina, peraluminosa de alto potássio, com idades $\mathrm{T}_{\mathrm{DM}}$ em 3,4 e 3,2 Ga $\left(\varepsilon_{\mathrm{Nd}} \approx-8\right)$. O Metagranitoide Grão Mogol é intrusivo no Ortognaisse Campos Gerais, apresenta composição tonalítica a monzogranítica e compõe uma série de rochas de afinidade subalcalina, calcioalcalina, peraluminosa, de alto potássio. Corpos circunscritos de metatonalito intrudem as unidades anteriormente descritas, com idade modelo $\left(\mathrm{T}_{\mathrm{DM}}\right)$ muito próxima das idades absolutas $(2,85 \mathrm{a} 2,77 \mathrm{Ga})$ e $\varepsilon_{\mathrm{Nd}}$ próximo a zero. O Granito Itapixé apresenta-se como um granito isotópico, levemente foliado, com afinidade subalcalina, calcioalcalina, peraluminosa, de alto potássio. O Granito Córrego do Sapateiro é uma rocha isotrópica, de granulometria média a grossa e coloração rosada. Pertence à série subalcalina, calcioalcalina, peraluminosa, de alto potássio. Os dados litogeoquímicos sugerem que os protólitos do Complexo Campos Gerais são relacionados à fusão de crosta oceânica metamorfisada (Ortognaisse Campos Gerais) e anatexia de crosta TTG (Ortognaisse Mandembo).
\end{abstract}

Palavras-chave: geoquímica; granitoides; Arqueano; Brasil.

Abstract Lithogeochemistry of Campos Gerais Complex and its intrusive granitoids, Archean/Paleoproterozoic, Brazil. The Campos Gerais Complex is located near the southwestern border of the São Francisco Craton, in the Brasília Belt. It consists of mesoarqueans migmatized orthogneiss (Campos Gerais and Mandembo orthogneisses), associated with neoarchean granitoids, granites and tonalites with probably Paleoproterozoic age. The Campos Gerais Orthogneiss shows a migmatitic stromatic structure, with tonalitic to monzogranitic mesosome, composing a sub-alkaline, calc-alkaline, metaluminous to peraluminous suite. This unit exhibits $3.2 \mathrm{Ga}$ TDM model age $\left(\varepsilon_{\mathrm{Nd}}-4.6\right)$. The Mandembo Orthogneiss shows diatexitic to nebulitic structure. Its composition is predominantly tonalitic to syenogranitic forming a sub-alkaline, calc-alkaline, peraluminous high-K series, with 3.4 to $3.2 \mathrm{Ga}$ TDM ages $\left(\varepsilon_{\mathrm{Nd}} \approx-8\right)$. The Grão Mogol metagranitoid is intrusive in the Campos Gerais Orthogneiss, composing a series of rocks with sub-alkaline, calc-alkaline, peraluminous, high-K affinity. Metatonalitic bodies are intrusive in the units described above, and show model ages (TDM) very close to the absolute ages $(2.85$ to $2.77 \mathrm{Ga})$ and $\varepsilon_{\mathrm{Nd}}$ close to zero. The Itapixé Granite is isotropic granite, slightly foliated, with sub-alkaline, calc-alkaline, peraluminous, high-K affinity. The Córrego do Sapateiro Granite has an isotropic, medium to coarse-grained texture and pinkish color. It belongs to a sub-alkaline, calc-alkaline, peraluminous, high-K series. The lithogeochemical data suggest that the Campos Gerais Complex protoliths are related to the melting of metamorphosed oceanic crust (orthogneiss Campos Gerais) and anatexis of TTG crust (orthogneiss Mandembo).

Keywords: geoquemistry; granitoids; Archean; Brazil.

INTRODUÇÃO O Complexo Campos Gerais (CCG) (Fig. 1) ocorre próximo à porção meridional do Cráton do São Francisco representando um segmento de crosta arqueana, intrudida por magmatismo discreto no Paleoproterozoico e retrabalhada durante a Orogenia Brasiliana.

A partir da definição inicial (Cavalcante et al. 1979), suas unidades litodêmicas sofreram mudanças e redefinições consideráveis. Inicialmente o complexo englobava toda a porção crustal posicionada entre as nappes de Passos e Varginha-Guaxupé, composta principalmente por ortognaisses, rochas metaultramáficas e rochas metassedimentares subordinadamente associadas.

Posteriormente novas subdivisões propuseram um domínio a norte, contendo ortognaisses e

\footnotetext{
${ }^{1}$ Departamento de Geologia, Universidade Federal do Espírito Santo - UFES, Vitória (ES), Brasil. E-mail: caio.rangel@ufes.br ${ }^{2}$ Grupo de Estudos em Geotectônica - TEKTOS, Faculdade de Geologia, Universidade do Estado do Rio de Janeiro - UERJ, Rio de Janeiro (RJ), Brasil. E-mail: cmval@uerj.br

*Autor correspondente
} 
sequências do tipo greenstone belts e outro a sul, com paragnaisses, metapelitos e rochas metamáficas da faixa Jacuí-Bom Jesus da Penha (Crosta et al. 1986, Szabó et al. 1993).

Turbay et al. (2008) propuseram a restrição do Complexo Campos Gerais para o domínio dos ortognaisses e granitoides intrusivos associados, excluindo assim os terrenos do tipo greenstone belt e as sequências metassedimentares mais jovens.

A complexidade litológica e geoquímica verificada no conjunto ortognáissico induz à necessidade da limitação do complexo a este grupo. Desta forma, este trabalho traz os resultados da caracterização litogeoquímica do Complexo Campos Gerais sob o ponto de vista do conjunto ortognáissico, bem como dos granitoides intrusivos associados.

Para isso, as unidades litodêmicas estudadas tiveram suas amostras analisadas para seus elementos maiores, traços e elementos terras raras (ETR).

Para complementação dos dados litogeoquími$\cos$ foram obtidos $\varepsilon \mathrm{Nd}$ e idade modelo (Tdm) $\mathrm{Sm} / \mathrm{Nd}$ de algumas das unidades litodêmicas.

MATERIAIS E MÉTODOS As análises litogeoquímicas (Tab. 1) para elementos maiores e grande parte dos elementos traços foram realizadas pelo método inductively coupled plasma - atomic emmission spectrometry (ICP-AES). Os ETR foram analisados pelo método inductively coupled plasma - mass spectrometry (ICP-MS).

As análises isotópicas para o sistema $\mathrm{Sm}-\mathrm{Nd}$ foram realizadas pelo método de diluição isotópica em espectrômetro de massa com ionização térmica (TIMS), modelo TRITON-Finnigan em modo multicoletor, utilizando-se coletores do tipo Faraday em modo estático. As idades modelo foram calculadas com base nas datações U-Pb em zircões (Valeriano et al. 2006), realizadas em algumas das amostras aqui estudadas (AC-37A, AC-15, AC-19, AC-26; Tab. 2).

Os dados litogeoquímicos incluem elementos maiores, expressos em porcentagem de peso $\left(\mathrm{SiO}_{2}, \mathrm{TiO}_{2}, \mathrm{Al}_{2} \mathrm{O}_{3}, \mathrm{Fe}_{2} \mathrm{O}_{3 \mathrm{t}}, \mathrm{MnO}, \mathrm{MgO}, \mathrm{CaO}\right.$, $\mathrm{Na}_{2} \mathrm{O}, \mathrm{K}_{2} \mathrm{O}, \mathrm{P}_{2} \mathrm{O}_{5}$ ), elementos traços incompatíveis móveis ( $\mathrm{Ba}, \mathrm{Rb}$ e $\mathrm{Sr}$ ), incompatíveis imóveis ( $\mathrm{Zr}$, Y e Nb), compatíveis (Ni, Cr, V, Co), ETR (La, Ce, Pr, Nd, Sm, Eu, Gd, Tb, Dy, Ho, Er, Tm, Yb e Lu) e U, Th, Hf, Ta e $\mathrm{Pb}$.

$\mathrm{O}$ ferro de todas as amostras estudadas foi analisado como ferro total expresso sob a forma de ferro férrico $\left(\mathrm{Fe}_{2} \mathrm{O}_{3} \mathrm{t}\right)$. Os valores de perda ao fogo (LOI) das amostras são, na maioria, inferiores a 1,5\%. Todas as análises foram recalculadas para base anidra.

Os dados resultantes das análises químicas para rocha total foram tratados no software Newpet (freeware).

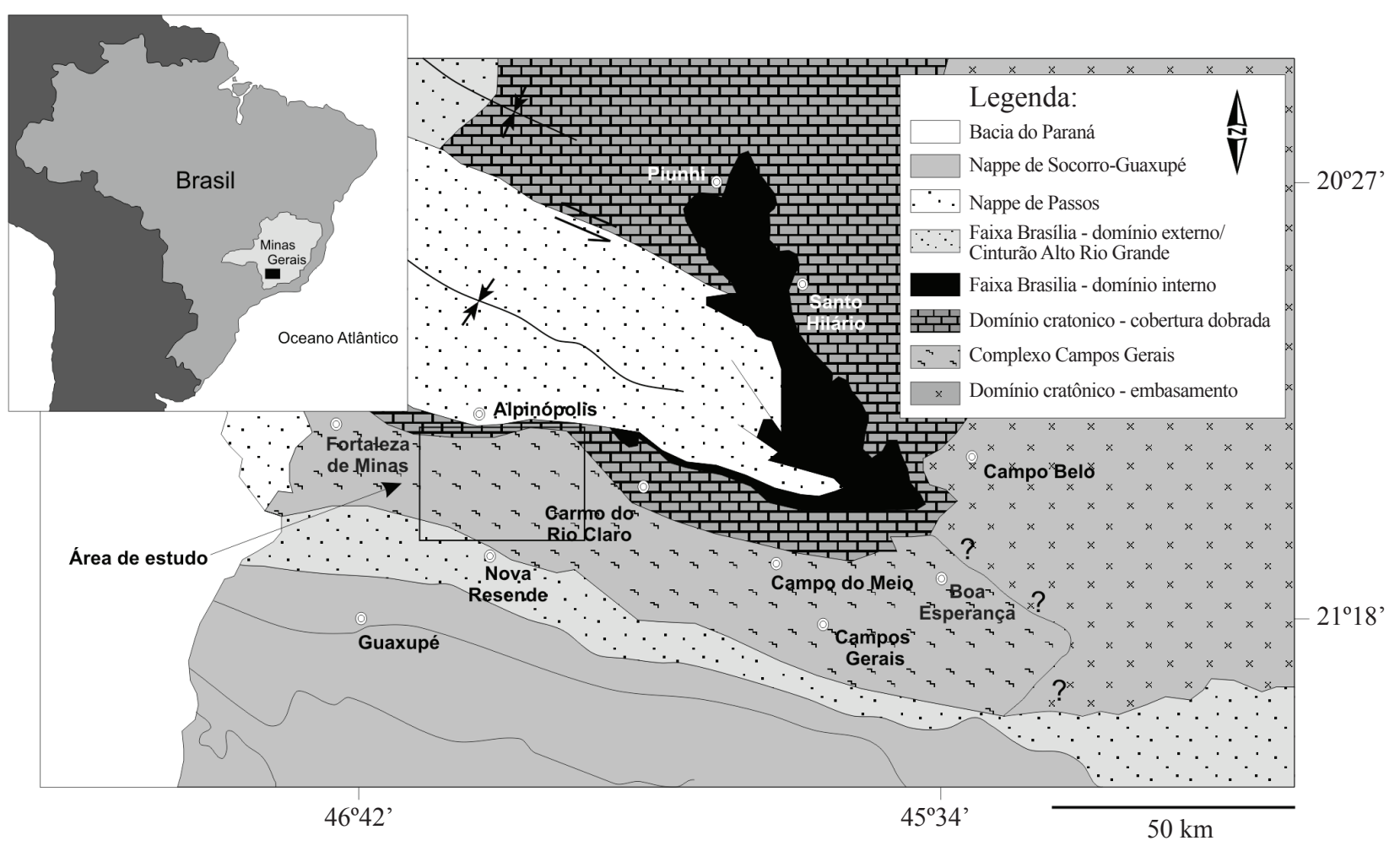

Figura 1-Localização da área de estudos no contexto geotectônico regional. Modificada de Valeriano et al. (2004). 


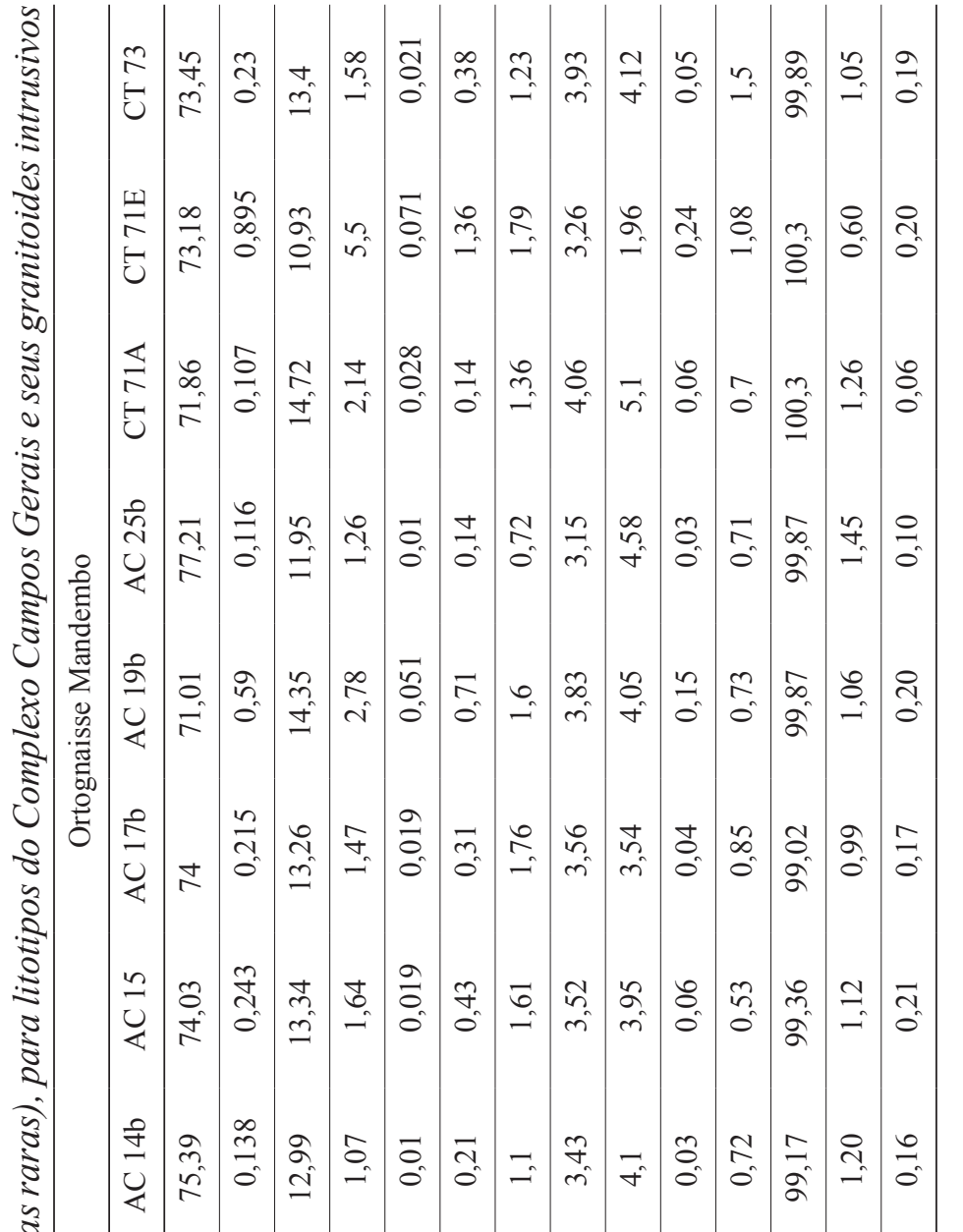

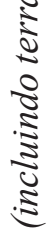

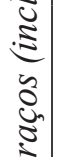

2ิ
ร 초ำ

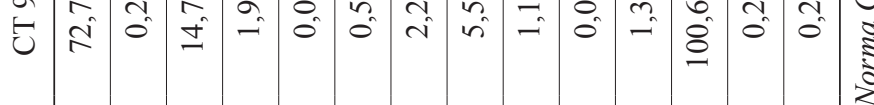

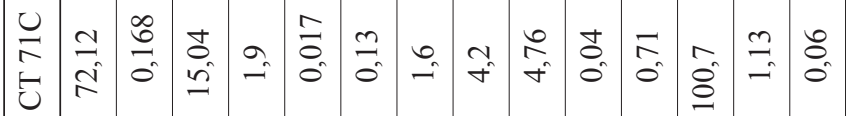

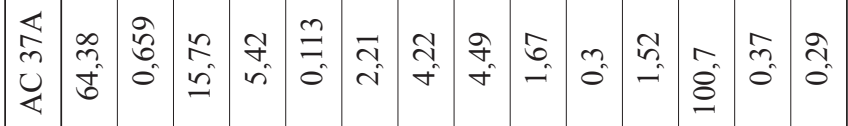

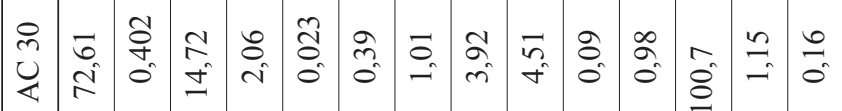

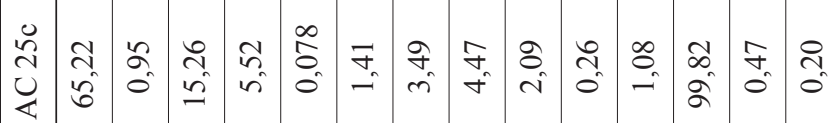

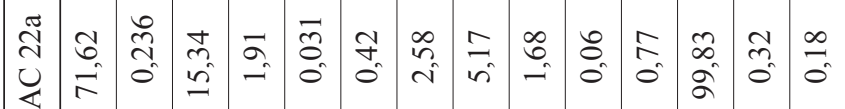

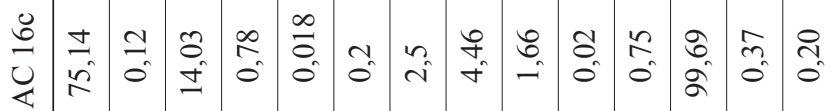

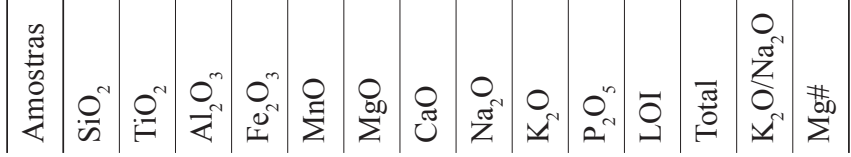

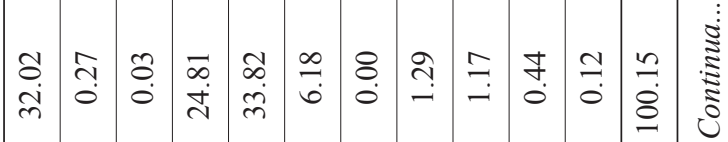

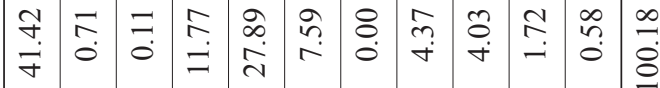

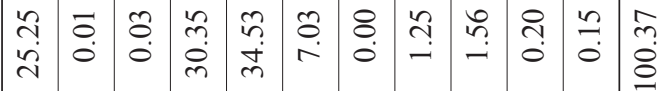

官

च

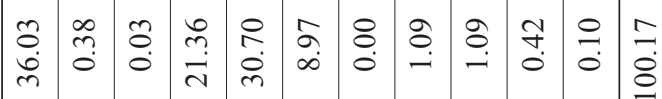

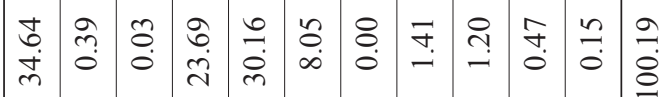

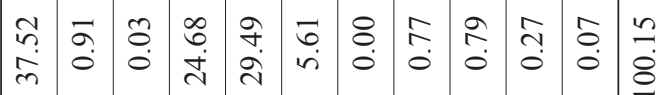

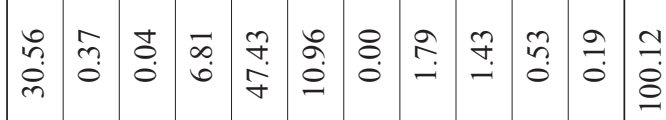

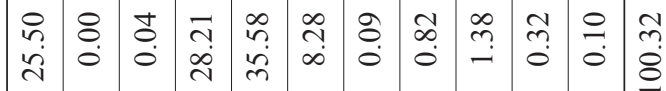

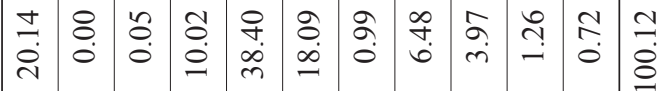

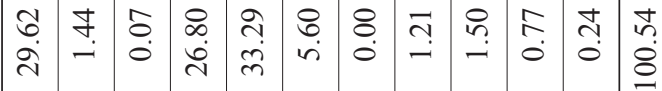

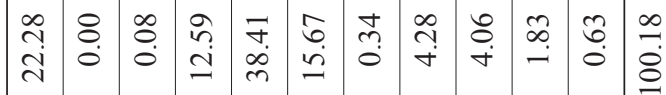
J

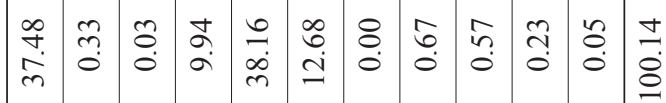

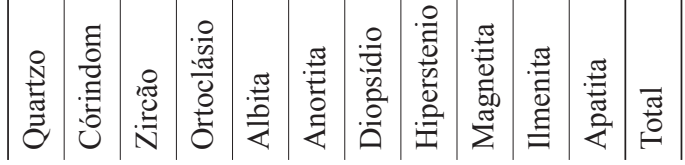




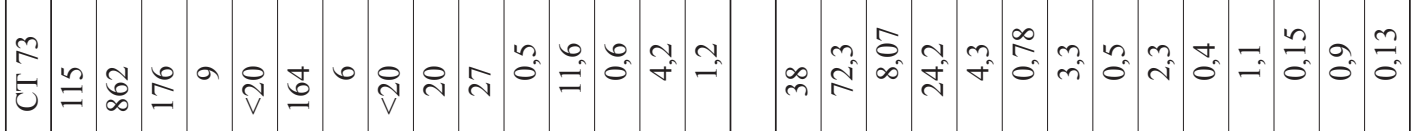

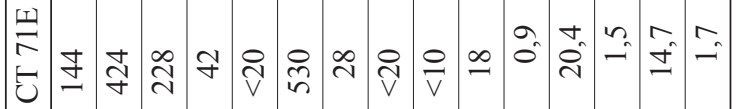

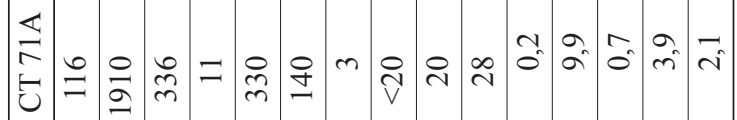

ํำ

离

.

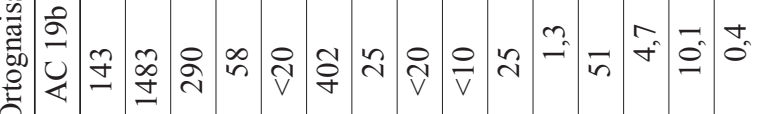

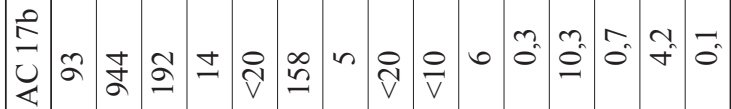

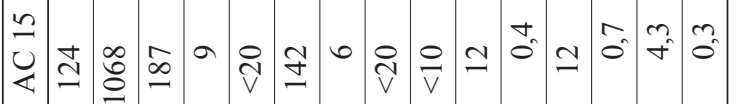

f

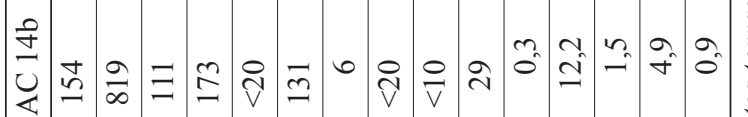

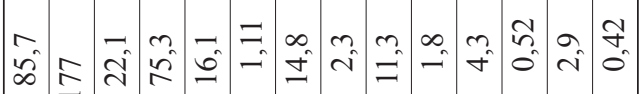

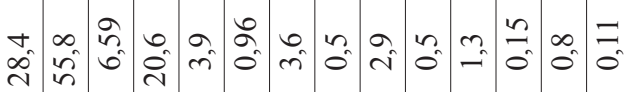

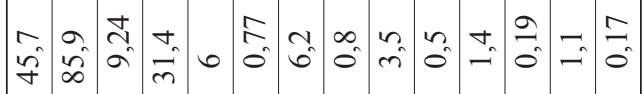

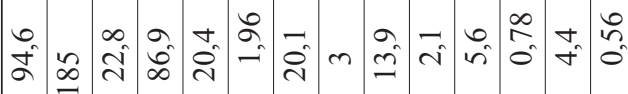

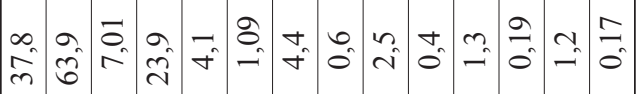

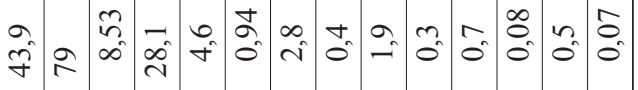

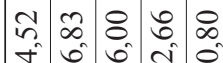

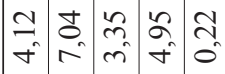

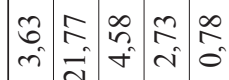

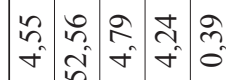

요요요.

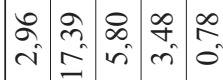

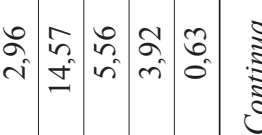

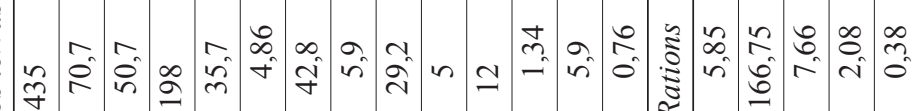

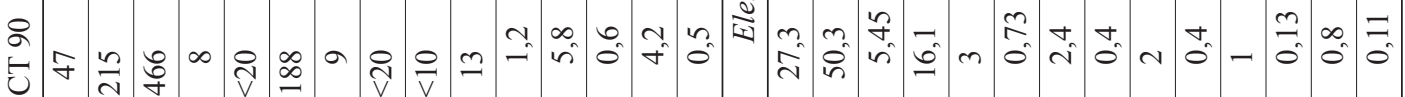

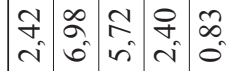

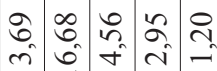

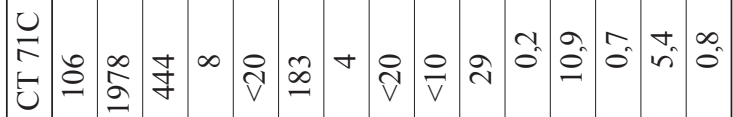

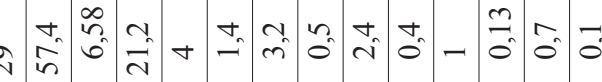

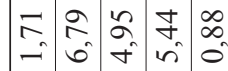

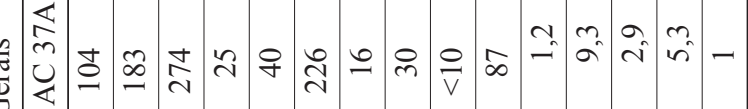

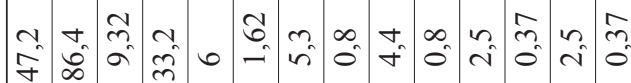

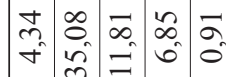

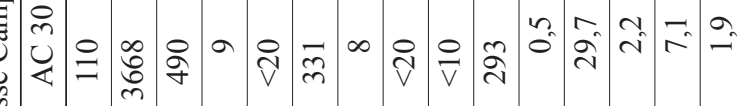

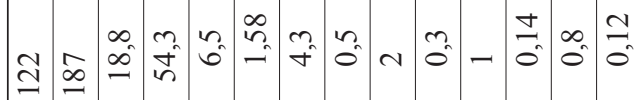

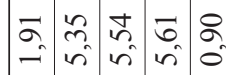

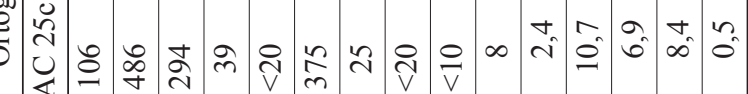

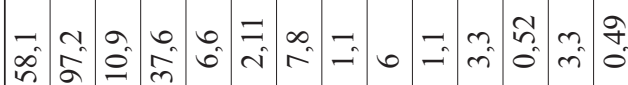

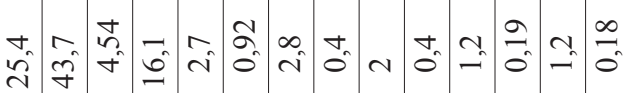

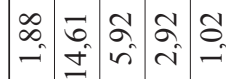

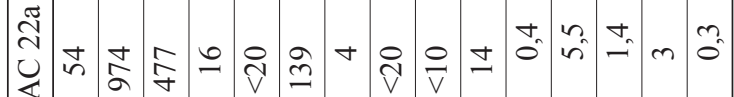

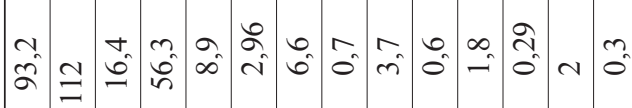

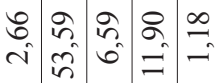

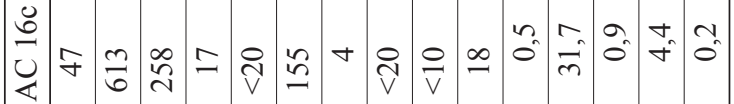




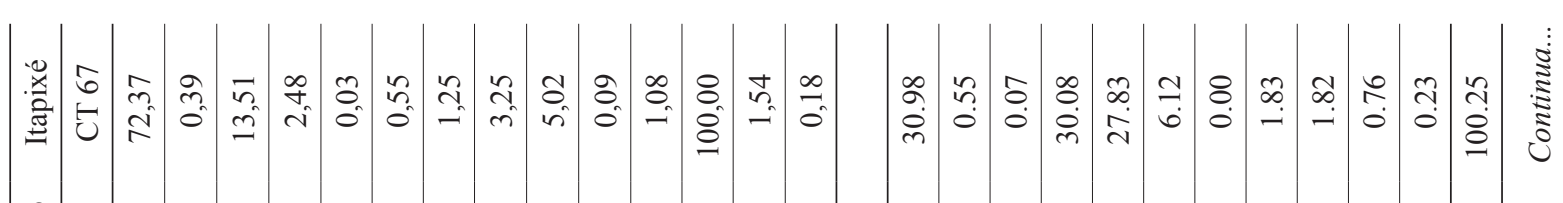

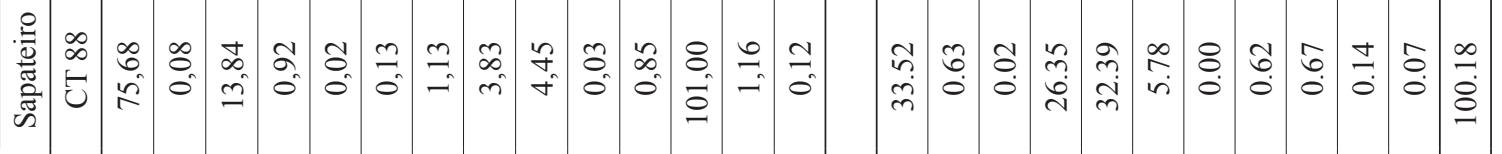

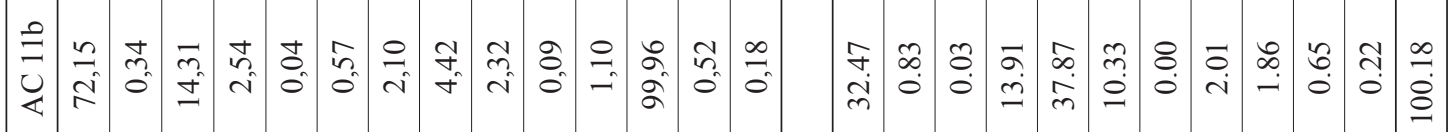

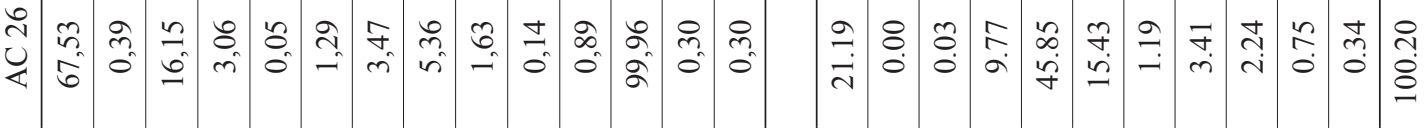

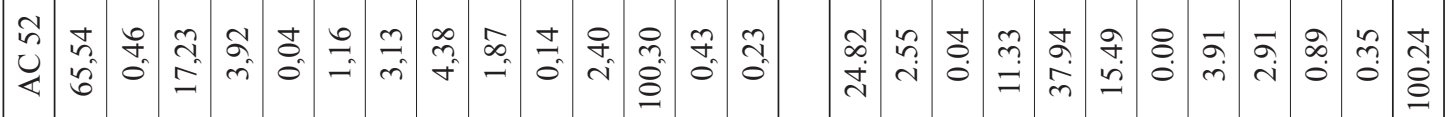

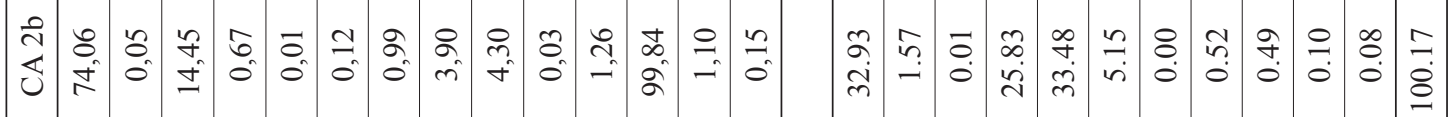

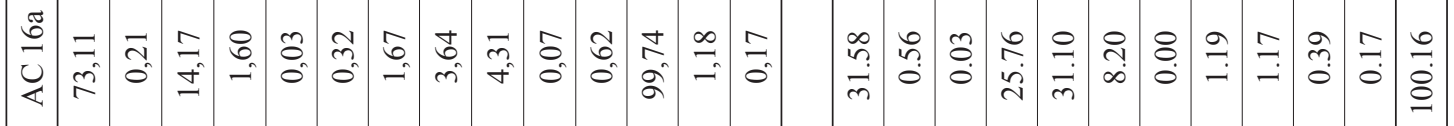

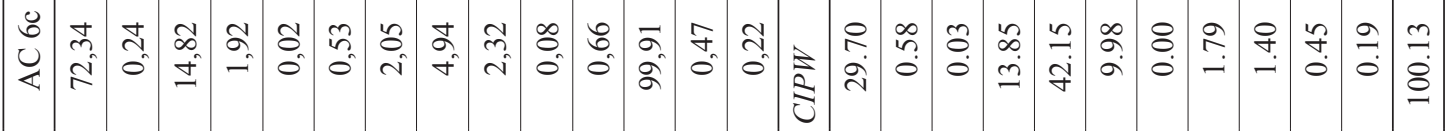

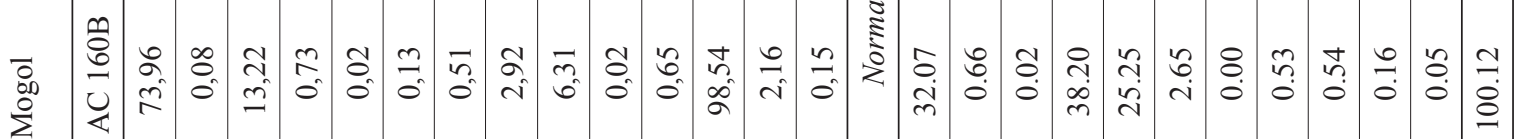

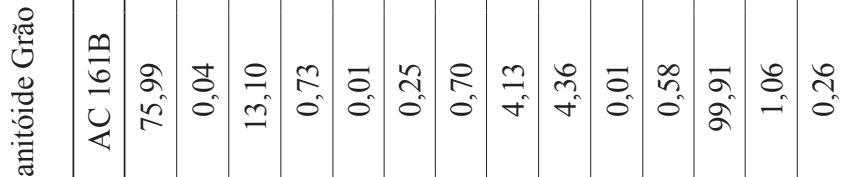

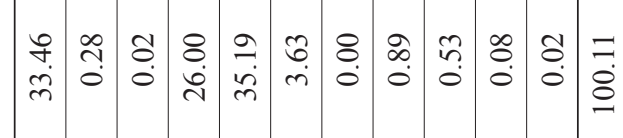

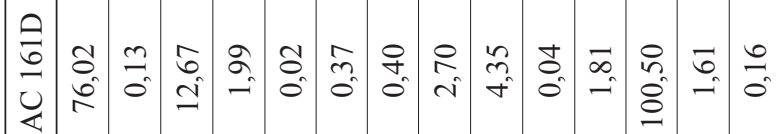

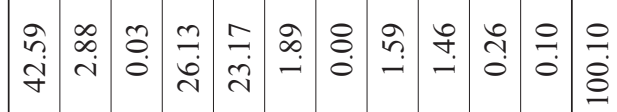

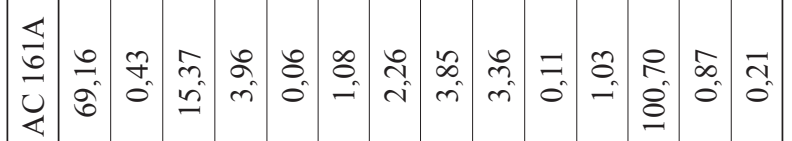

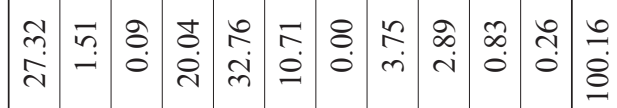

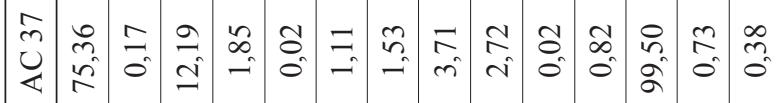

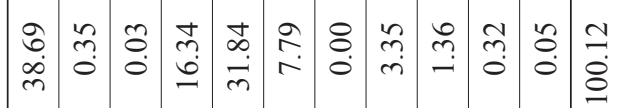

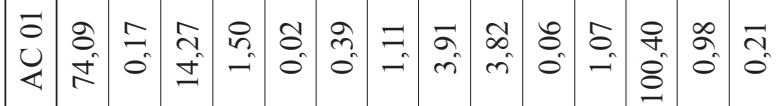

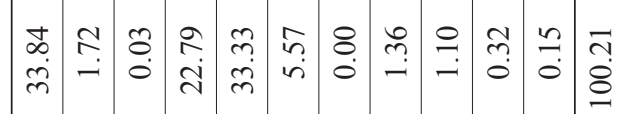




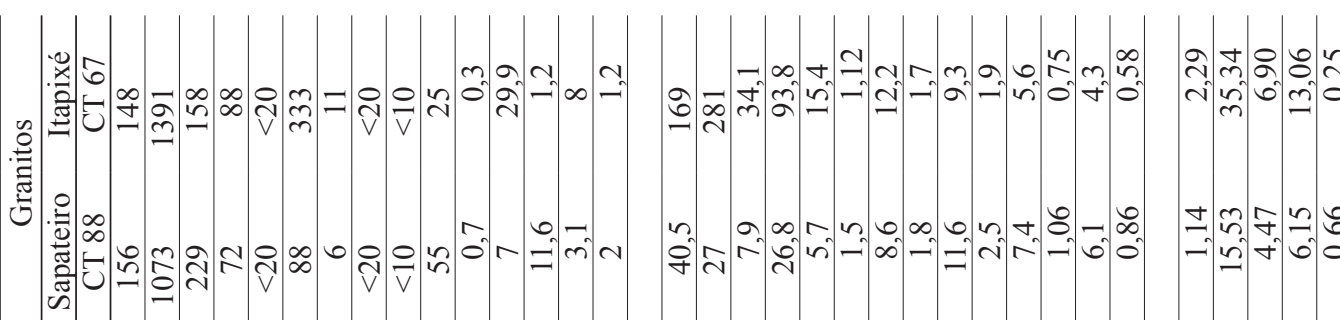

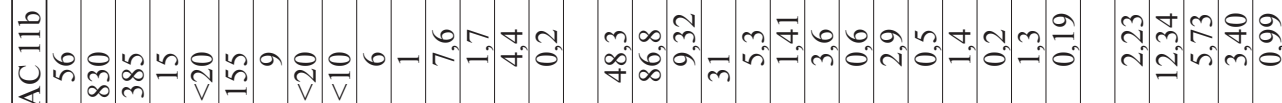

:

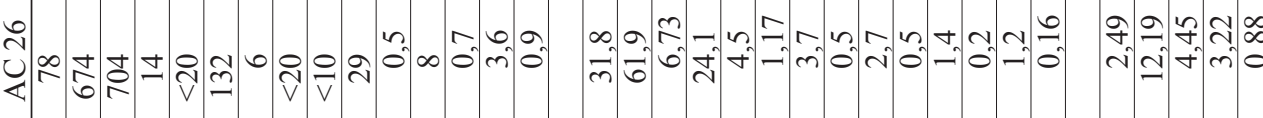

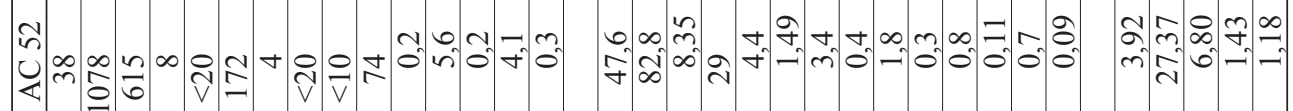

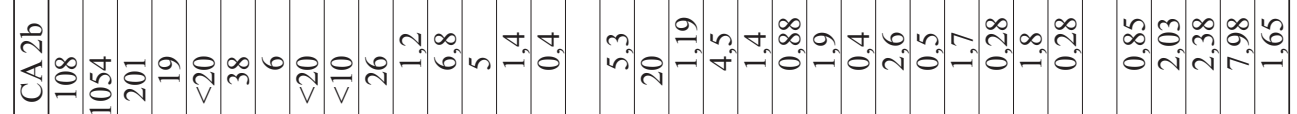

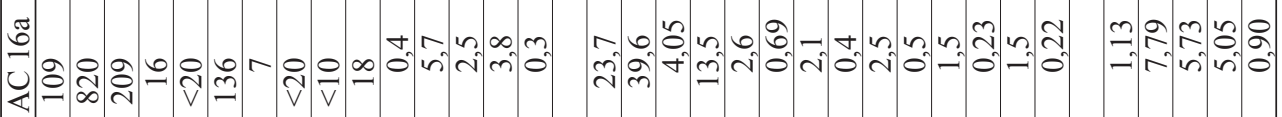

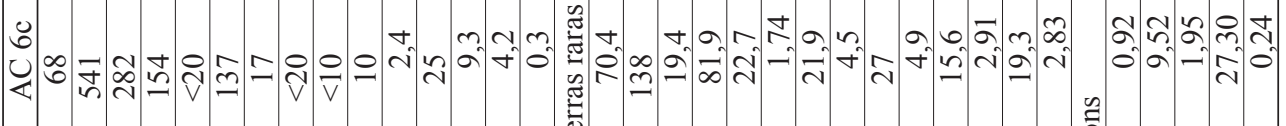

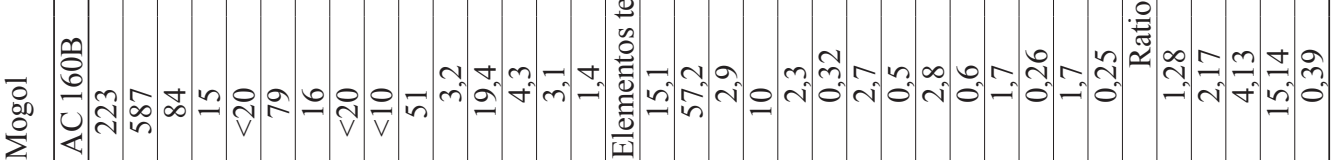
ษ్తై 苛 节

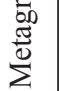

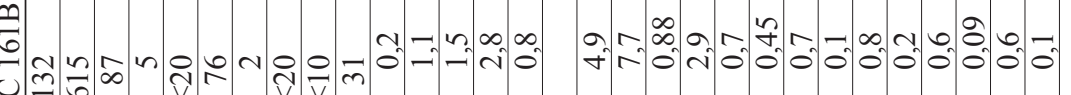

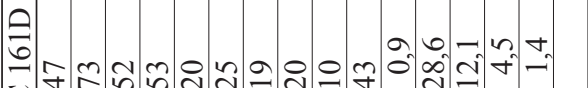
艺

$\varangle$

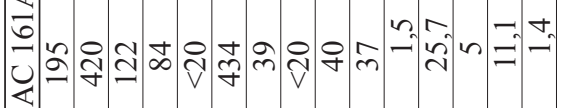

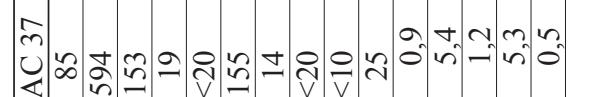

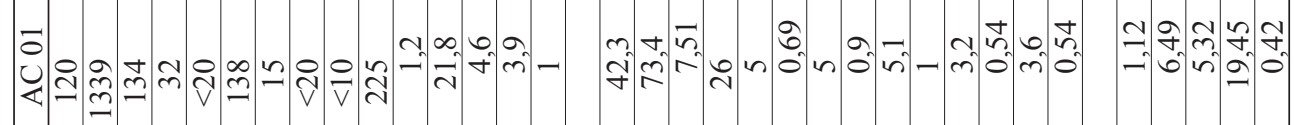

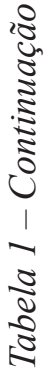

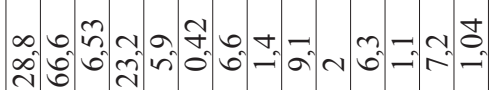

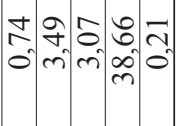

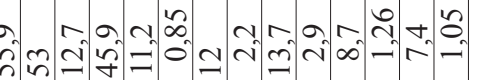

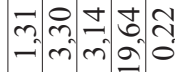

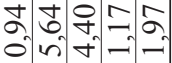

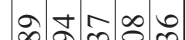

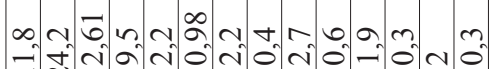

क.

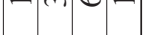

Z ट्रे उ) |z

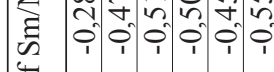

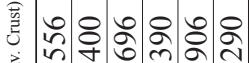
$\because$ ن ले लें

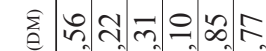
- m m ma

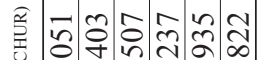

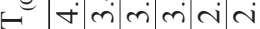

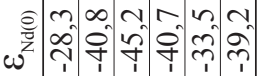

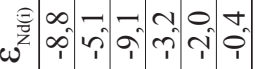
올

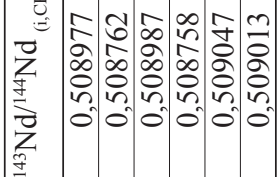

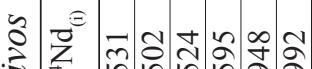

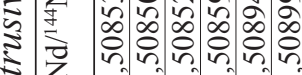
告 0000000

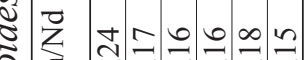
: $\left.\frac{0}{5} \approx \approx+\infty\right)$

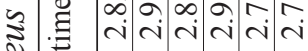
○) ปे चี (2) 2) 를 $\cong \circ$ 先

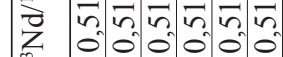
苍告

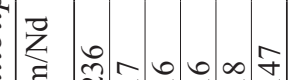
क ती की

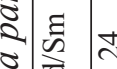

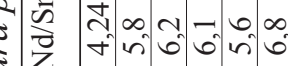
$\frac{2}{2}$

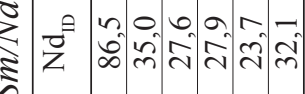

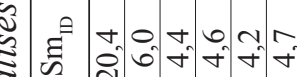
赵 悉

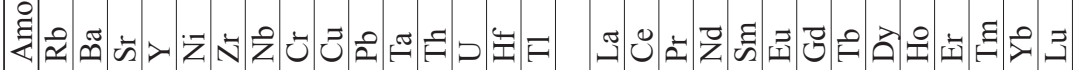

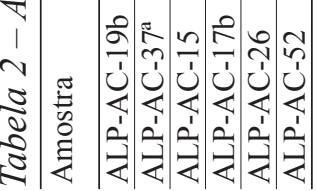




\section{O COMPLEXO CAMPOS GERAIS NO} CONTEXTO EVOLUTIVO DO CRÁTON DO SÃO FRANCISCO O Cráton do São Francisco representa uma unidade continental individualizada durante o Neoproterozoico, ao final da Orogenia Brasiliana/Pan-africana (Teixeira et al. 2000).

Os primeiros registros orogênicos no interior do cráton coincidem com períodos de maior crescimento crustal observados em outras áreas do planeta entre 2,9 e 2,7 Ga, sendo responsáveis pela aglutinação de pequenas porções crustais, magmatismo pós-orogênico em 2,6 Ga (Noce, Machado, Teixeira 1998) e a formação do Cráton do Paramirim (Teixeira et al. 2000).

Durante o Paleoproterozoico, o Cráton do Paramirim funcionou como o antepaís de faixas orogênicas hoje expostas no sudoeste de Minas Gerais e nordeste da Bahia, a partir do qual foram formados terrenos do tipo migmatito-granito-greenstone e granitoides $\sin$ a tardi colisionais (Alkmim 2004).

Em Minas Gerais, o cinturão orogênico paleoproterozoico é conhecido como Cinturão Mineiro (Teixeira et al. 2000) e abarca o Quadrilátero Ferrífero e porções a sul-sudoeste, circundando zonas crustais arqueanas intactas ou parcialmente remobilizadas, como resultado da acresção de arcos de ilhas e terrenos exóticos (Alkmim \& Marshak 1998). Em resumo, o Cinturão Mineiro é composto por granitoides e intrusões máficas, colocadas em crosta do tipo granito-greenstone arqueana, remobilizada a 2,1 e 2,0 Ga (Noce, Machado, Teixeira 1998, Quéméneur $\&$ Noce 2000).

$\mathrm{O}$ antepaís relacionado à orogenia paleoproterozoica é composto por complexos metamórficos, exibindo terrenos ortognáissicos do tipo TTG, granitoides e sequências vulcanossedimentares arqueanas $(3,0$ a $2,8 \mathrm{Ga})$, retrabalhados por eventos metamórficos entre 2,7 e 2,6 Ga (Noce, Machado, Teixeira 1998, Campos, Carneiro, Basei 2003).

Nas adjacências do Quadrilátero Ferrífero, os complexos Belo Horizonte e Bonfim exibem segmentos de crosta arqueana ortognáissica tipo TTG de 2,9 a 2,8 Ga, associados a intrusões de 2,7 a 2,6 Ga (Noce, Machado, Teixeira 1998). Idades para migmatização mais ou menos expressiva ocorrem entre 2,2 e 2,1 Ga (Carneiro et al. 1997; Noce, Machado, Teixeira 1998).

No Complexo Passa Tempo, a sudoeste do Complexo Belo Horizonte, datações U-Pb em migmatitos forneceram idades de 2,6 Ga para o metamorfismo, migmatização e granitogênese (Campos, Carneiro, Basei 2003).

O Complexo Campo Belo, na porção meridional oeste do Cráton do São Francisco, exibe três gerações de fusões, determinadas por geocronologia $\mathrm{U} / \mathrm{Pb}$ (Teixeira et al. 1998). Zircões mais antigos datados de 3,2 Ga são interpretados como herdados de uma crosta pretérita. Um segundo grupo mostra idade de 3,0 Ga, interpretada como principal evento magmático formador de protólitos de ortognaisses pouco migmatizados, expostos próximos à cidade de Campo Belo. Populações mais jovens mostram idades de 2,8 Ga, consideradas como a idade de cristalização do neossoma dos ortognaisses migmatíticos (Teixeira et al. 1998).

Nas imediações da porção sudoeste do cráton, o Complexo Campos Gerais aparece como uma extensão geneticamente relacionada ao seu embasamento arqueano. Ele apresenta predominantemente um conjunto ortognáissico migmatítico, atingido por tectônica neoproterozoica, gerando estruturação segundo WNW-ESSE. Extensas zonas de cisalhamento dúctil a rúptil, de movimentação predominantemente sinistral, aparecem cortando a unidade (Fig. 1) e são relacionadas ao Cinturão de Cisalhamento Campo de Meio (Morales \& Hasui 1993).

Os mapas de Szabó (1989) e Turbay et al. (2008), que abrangem a área entre as cidades de Alpinópolis e Nova Resende, distinguiram nesta faixa os seguintes domínios litodêmicos: ortognaisses tonalíticos a monzograníticos migmatizados, rochas ultramáficas intercaladas a formações ferríferas bandadas compondo terrenos do tipo greenstone belt, granitoides intrusivos arqueanos e paleoproterozoicos, Klippen e lascas tectônicas de sequências metassedimentares neoproterozoicas (grupos Araxá e Andrelândia) (Fig. 2).

$\mathrm{O}$ estudo das sequências supracrustais do tipo greenstone determinou condições metamórficas na fácies anfibolito na região (Zanardo et al. 1990), embora Szabó (1989) tenha encontrado paragêneses que indicam a transição entre a fácies xisto-verde e anfibolito. Para leste, nos domínios do Complexo Metamórfico Campo Belo, as paragêneses minerais mostram que o pico metamórfico foi atingido dentro dos limites da fácies granulito, com retrometamorfismo em fácies anfibolito e xisto-verde (Corrêa da Costa 1999, Fernandes 2001). É notório, no entanto, que as zonas de cisalhamento sinistrais foram responsáveis pelo retrometamorfismo na fácies anfibolito 

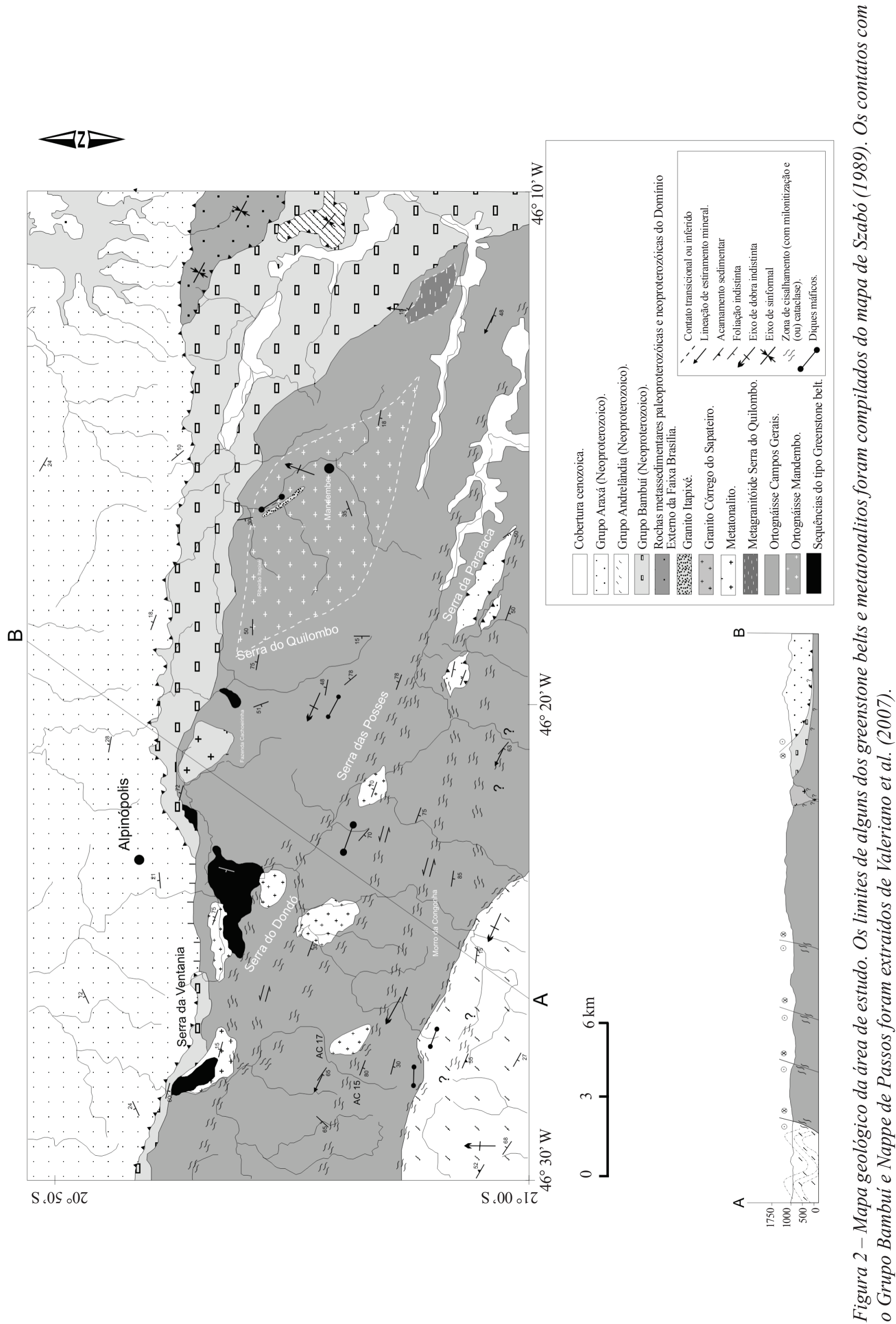
e xisto-verde (Roig \& Schrank 1992, Szabó 1992, Carvalho et al. 1993).

Isócronas $\mathrm{Rb}-\mathrm{Sr}$ realizadas na faixa ortognáissica predominante deste complexo revelaram idade de cristalização de seus protólitos em $2,8 \mathrm{Ga}$, com intrusões de granitoides a 2,1 e 1,9 Ga (Teixeira et al. 1989).

\section{O COMPLEXO CAMPOS GERAIS AO SUL DE} ALPINÓPOLIS Conforme já dito, o conjunto litológico nesta região é constituído principalmente por ortognaisses migmatíticos - Complexo Campos Gerais de Turbay (2010) —, onde estão inseridas quilhas tectônicas supracrustais do tipo greenstone belt, correlacionadas ao greenstone do Morro do Ferro, em Fortaleza de Minas (Teixeira et al. 1987, Carvalho et al. 1993). Este substrato é intrudido por corpos circunscritos de metatonalitos e granitos, além de diques máficos e metamáficos diversos. Klippen e lascas tectônicas de sequências metassedimentares neoproterozoicas correlacionadas ao Grupo Araxá e Andrelândia são observadas. Formam pequenas serras localizadas sobre o embasamento ortognáissico ou como terrenos em contato tectônico lateral (transcorrência) a sul-sudeste. Ao norte, o Complexo Campos Gerais é recoberto pela cobertura cratônica neoproterozoica do Grupo Bambuí e pela Nappe de Passos (Fig. 2).

Grande parte da faixa aflorante dos ortognaisses é atravessada por zonas de cisalhamento sinuosas e anastomosadas, de caráter dúctil a dúctil-rúptil e movimentação oblíqua sinistral. Estas zonas são responsáveis por embutir as quilhas e lascas das sequências supracrustais arqueanas e neoproterozoicas entre o embasamento ortognáissico, induzindo às rochas deformação heterogênea, com zonas levemente deformadas, eventualmente protomiloníticas e zonas miloníticas a ultramiloníticas, com larguras de até $2 \mathrm{~km}$. A porção nordeste da área de estudos apresenta deformação tênue ou ausente, sem o desenvolvimento de foliação milonítica.

Quatro fases deformacionais foram identificadas no embasamento ortognáissico. A primeira fase é responsável pela geração de foliação $S_{1}$ no mesossoma do Ortognaisse Campos Gerais. Dobras $\mathrm{D}_{2}$ desarmônicas, inclinadas, são vistas localmente dobrando a foliação $S_{1}$ do Ortognaisse Campos Gerais. Em geral possuem eixo com mergulho para norte, na ordem de $330^{\circ} / 60^{\circ}$ e plano axial $\mathrm{S}_{2}$ mergulhando $75^{\circ}$ para WSW. As zonas de cisalhamento sinistrais são responsáveis pela formação de foliação milonítica $\mathrm{S}_{3}$, subparalela a $\mathrm{S}_{1}$ com mergulhos predominantes de $55^{\circ}$ a $75^{\circ}$ para $S W$, com eventuais superfícies do tipo $S$ - $C$ conjugadas. Associada a $\mathrm{S}_{3}$ milonítica ocorre lineação de estiramento $\left(\mathrm{L}_{3}\right)$ com caimento de baixo ângulo para WNW e ESSE. A quarta e última fase de deformação caracteriza-se por dobras suaves com eixos que caem para NNW em baixo ângulo e inflexionam a lineação $\mathrm{L}_{3}$.

Paragêneses com presença de muscovita/sericita \pm clorita \pm epídoto observadas nos ortognaisses e no Metagranitoide Grão Mogol, principalmente nas proximidades das zonas de cisalhamento, indicam metamorfismo na fácies xisto-verde. No Metatonalito, o processo é indicado pela transformação de hornblenda primária em actinolita \pm biotita \pm clorita e, pela presença de epídoto.

Idades obtidas no Complexo Campos Gerais por ablação a laser (Valeriano et al. 2006), indicam cristalização de protólitos em $2,95 \pm 20 \mathrm{Ma}$ (Ortognaisse Campos Gerais) 2,82 \pm 69 Ma e $2,81 \pm 15 \mathrm{Ma}$ (Ortognaisse Mandembo), com heranças de 3,6, 3,3 e 3,1 Ma. Dados de metatonalito intrusivo no complexo exibiram idade de cristalização em 2,77 \pm 21 Ma.

\section{Unidades litodêmicas}

COMPLEXO CAMPOS GERAIS É formado por um substrato essencialmente migmatítico, que engloba tipos faciológicos metatexítico estromático a diatexítico com estrutura schlieren e nebulítica.

Com base nas estruturas observadas em campo, texturas em escala macro e mesoscópica e conteúdo mineralógico, estes ortognaisses podem ser divididos em dois grupos, aqui denominados Ortognaisse Campos Gerais e Ortognaisse Mandembo.

ORTOGNAISSE CAMPOS GERAIS É um gnaisse metatexítico, estromático (Fig. 3A), de mesossoma composto por rocha foliada de coloração cinza esverdeada de granulação fina, composição tonalítica a monzogranítica. Normalmente, o melanossoma é composto por concentrações lenticulares de biotita e eventualmente hornblenda. O leucossoma apresenta granulação média a grossa, composição monzogranítica a sienogranítica, formando bolsões pegmatoides ou veios aplíticos concordantes ou discordantes da foliação.

Microscopicamente observa-se textura inequigranular, de granulação fina a média, predominantemente 

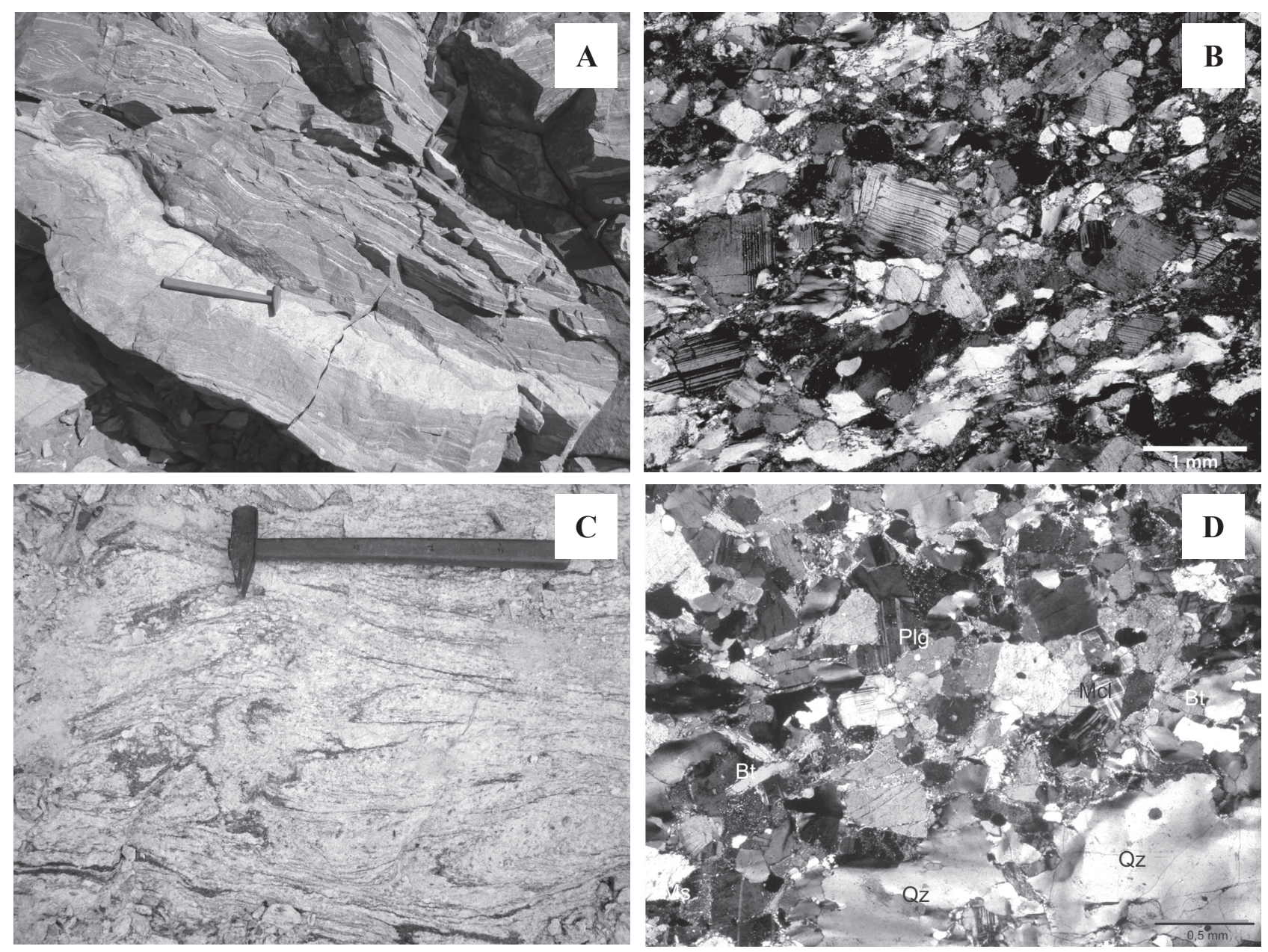

Figura 3 - (A) Estrutura migmatítica estromática no Ortognaisse Campos Gerais. Observar o aspecto cinza escuro e foliado do mesossoma em contraste com o leucossoma; (B) Fotomicrografia do mesossoma do Ortognaisse Campos Gerais exibindo textura granoblástica protomilonítica (polarizadores cruzados); (C) Mistura de termos nebuliticos e schlieren no Ortognaisse Mandembo; (D) Vista geral do Ortognaisse Mandembo exibindo textura granoblástica. A textura holocristalina hipidiomórfica do protólito se mantém parcialmente preservada (polarizadores cruzados).

granoblástica, dada pela disposição em contatos tríplice de cristais anédricos de quartzo e subédricos de feldspatos a granolepidoblástica, onde a biotita desenvolve orientação segundo a foliação do mesossoma. Localmente observa-se textura protomilonítica a milonítica (Fig. 3B).

Sua mineralogia é constituída principalmente por plagioclásio, microclina, quartzo e biotita, conferindo, de acordo com a proporção modal, composição tonalítica a monzogranítica aos protólitos. Duas gerações de plagioclásio são vistas. A primeira geração é geralmente anédrica e pode estar inclusa na segunda. A segunda apresenta hábito subédrico, exibindo ou não maclas, e maior grau de alteração para saussurita. A microclina ocorre como cristais anédricos a subédricos, com formatos ovalados a quadráticos. O quartzo é anédrico, intersticial, podendo mostrar recristalização dinâmica nas bordas ou formar fitas. A biotita é marrom, anédrica a subédrica, intersticial, associada à clorita, titanita e hornblenda. Pode ocorrer inclusa nos feldspatos e no quartzo ou mostrar sinais de desenvolvimento a partir de hornblenda. Entre os minerais acessórios figuram o epídoto, zircão, apatita, hornblenda, titanita e opacos. O epídoto está geralmente concentrado em veios ou associado a plagioclásios, sericita e saussurita. Raramente ocorre zoisita/clinozoisita. A hornblenda ocorre em pequena quantidade, principalmente nos gnaisses de composição tonalítica. Associa-se principalmente à biotita. Entre os produtos secundários observam-se clorita, saussurita e sericita.

ORTOGNAISSE MANDEMBO Caracteriza-se como um gnaisse migmatítico diatexítico, com estrutura schlieren a nebulítica (Fig. 3C).

Apresenta quantidade relevante de biotita, formando agregados dispersos de forma aleatória ao 
longo de planos sutis de foliação ou restitos em abundância, o que em parte permite sua diferenciação do leucossoma do Ortognaisse Campos Gerais e demais granitoides. Núcleos anfibolíticos adelgaçados ou rompidos ocorrem com frequência.

Contatos entre os dois ortognaisses não são observados em campo, principalmente devido à superposição da deformação milonítica que atinge grande parte da região.

Microscopicamente exibe textura granoblástica (Fig. 3D) a granolepidoblástica, eventualmente protomilonítica. Localmente é observada textura isotrópica equigranular a inequigranular de origem anatética, além de textura mirmerquítica.

Sua assembleia mineralógica principal é composta por quartzo, microclina, ortoclásio pertítico e plagioclásio. A proporção mineralógica modal confere aos protólitos composição tonalítica a sienogranítica.O quartzo possui contornos tipo embayment, eventualmente deformados, com formação de subgrãos no interior e nas bordas ou apresentando cristais estirados. O plagioclásio é subédrico, formando porfiroclastos grandes, fraturados, com maclas deformadas em kinks e tipos menores com maclas apagadas e superfície levemente saussuritizada. Sua composição predominante é andesina. A microclina apresenta cristais de granulação fina, subédricos a anédricos, enquanto que o ortoclásio pertítico forma porfiroclastos de granulação grossa e subédricos. Como minerais acessórios observam-se biotita, apatita, zircão e epídoto. A biotita é euédrica, menos comumente subédrica, normalmente orientada e raramente inclusa em plagioclásio, sugerindo, fortemente, origem primária. Apatita ocorre como cristais euédricos, de granulação fina, podendo estar inclusa em plagioclásio. Os produtos secundários são principalmente clorita, sericita e eventualmente saussurita.

\section{Granitoides intrusivos}

METAGRANITOIDE GRÃO MOGOL Engloba um conjunto de granitoides mesocráticos a leucocráticos, de textura homogênea, predominantemente isotrópica, inequigranular, de granulação média a grossa.

Possui caráter intrusivo e aflora em poucos locais. Seus contatos com o Ortognaisse Campos Gerais não foram observados em escala de mapeamento. Em escala de afloramento é possível identificar a intrusão do mesossoma do Ortognaisse Campos Gerais por vênulas aplíticas e camadas deste granitoide (Fig. 4A). Esta feição, na maioria das vezes, induz à acepção do conjunto formar um bandamento gnáissico simples (de uma só origem). No entanto, a observação detalhada confirma a textura isotrópica deste granitoide e sua distinção em relação à anisotropia das bandas félsicas dos ortognaisses Campos Gerais e Mandembo, inclusive no leucossoma.

O Metagranitoide Grão Mogol ocorre sustentando a Serra do Quilombo, sudeste de Alpinópolis, ou em um morro isolado a leste da Fazenda Grão Mogol, em direção à Carmo do Rio Claro.São rochas de textura predominantemente granoblástica (Fig. 4B), passando a protomilonítica/milonítica. Em algumas porções ocorre textura holocristalina, hipidiomórfica a xenomórfica, inequigranular, de granulação predominantemente fina a média e eventualmente grossa preservada. A composição de seus protólitos varia de termos tonalíticos a monzograníticos.

A mineralogia principal da rocha é composta por quartzo, plagioclásio e microclina. O quartzo é anédrico, intersticial, mostrando extinção ondulante ou formando subgrãos e ribbons nas porções mais deformadas. A microclina possui hábito subédrico quadrático a anédrico, apresentando cristais bem preservados, eventualmente micropertíticos, ocasionalmente cataclasados nos tipos protomiloníticos e miloníticos. Dois tipos de plagioclásio são observados. O primeiro tipo apresenta-se levemente saussuritizado, subédrico a anédrico. O outro tipo é límpido, bem preservado, subédrico, não raro com maclas bem evidentes, mostrando sinais de deformação ou desenvolvendo maclas "em chama" em meio à textura protomilonítica. Nas porções miloníticas apresentam-se cataclasados. Composicionalmente variam de andesina a labradorita. Como minerais acessórios ocorrem muscovita, biotita, clorita, opacos, apatita, zircão e granada. Muscovita aparece em quantidades variáveis, sempre inferiores a $3 \%$, como cristais euédricos a subédricos, de granulação fina a média, geralmente associada a biotita e clorita. Pode estar deformada, exibindo dobras ou recristalização em suas bordas. Epídoto ocorre em quantidades variáveis, aumentando geralmente nas proximidades das zonas de cisalhamento.Biotita ocorre normalmente em pequena quantidade. Possui hábito euédrico a subédrico, granulação fina a média, coloração marrom clara a verde oliva, frequentemente associada à clorita. Feições de inclusão parcial em quartzo anédrico com contornos em embayment podem ser um indicador do caráter primário deste mineral. Os minerais opacos são euédricos a anédricos, associados à 

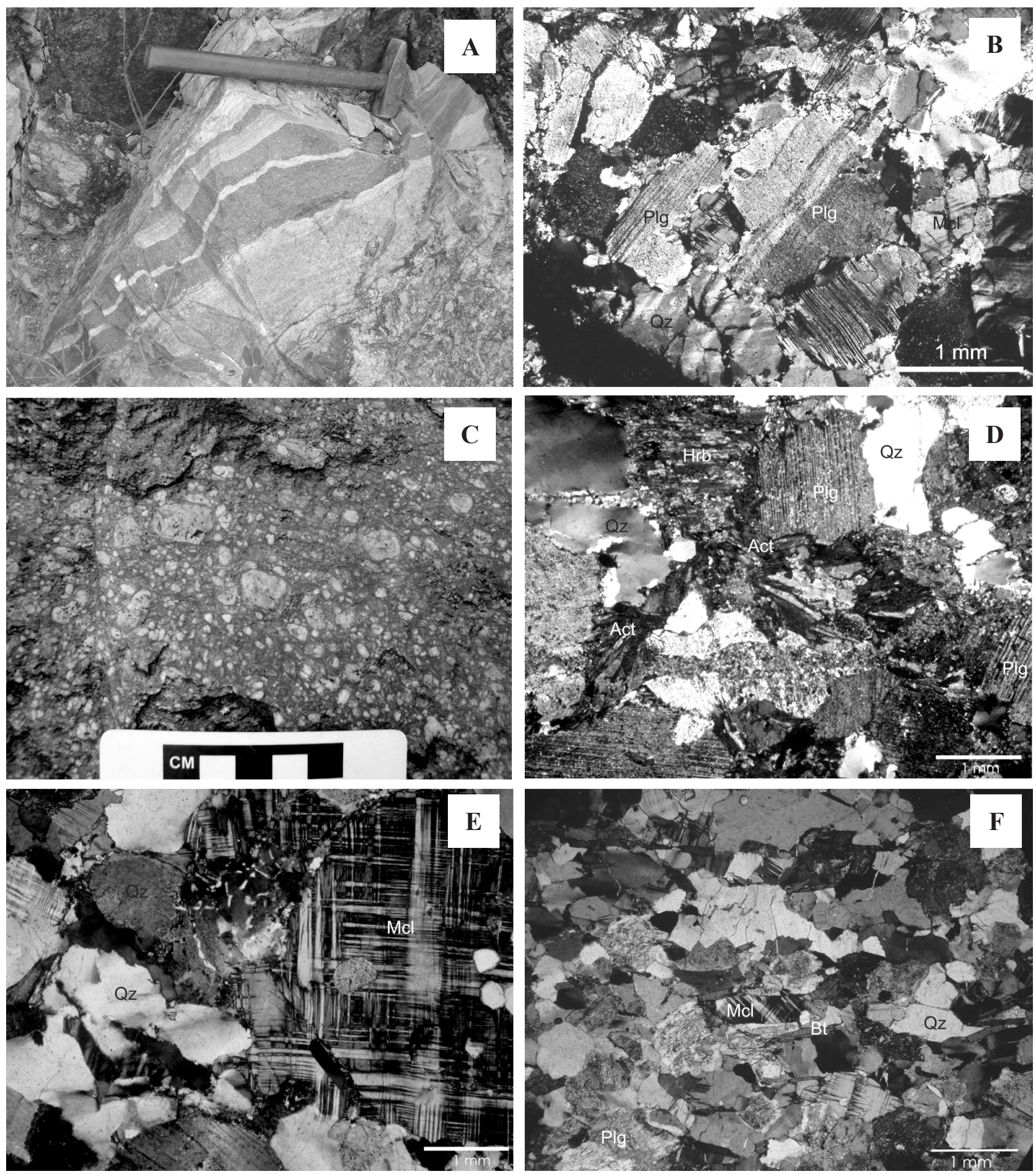

Figura 4 - (A) Mesossoma do Ortognaisse Campos Gerais intrudido por vênulas aplíticas e camadas decimétricas do Metagranitoide Grão Mogol, conferindo ao conjunto aspecto bandado; (B) Fotomicrografia exibindo textura granoblástica no Metagranitoide Grão Mogol; (C) Aspecto porfiritico do metatonalito, denotado pela presença de fenocristais de plagioclásio em matriz microfanerítica; (D) Fotomicrografia de metatonalito exibindo retrometamorfismo de hornblenda para actinolita (polarizadores cruzados); (E) Granito Córrego do Sapateiro exibindo textura mirmequitica (polarizadores cruzados); (F) Granito Itapixé mostrando deformação tênue, denotada pelos contatos tríplice entre grãos. A orientação dos cristais se deve provavelmente à herança de fluxo magmático (polarizadores cruzados). Plg: Plagioclásio; Mcl: Microclina; Qz: Quartzo; Bt: Biotita; Hbl: Hornblenda; Act: Actinolita.

biotita e plagioclásio, ocasionalmente preenchendo fraturas. No concentrado de minerais pesados obtidos por moagem e separação por densidade observou-se que a sua assembleia é composta por pirita limonitizada, ilmenita, magnetita e xenotímio. O epídoto ocorre disseminado pela rocha ou preenchendo fraturas, quando então se associa com sericita e carbonato secundário. 
METATONALITO Formam corpos ovalados a arredondados com dezenas a centenas de metros de diâmetro, representados por aglomerados de blocos e matacões in situ ou parcialmente deslocados, dispersos na superfície do terreno.

São rochas relativamente homogêneas, isotrópicas, com evidências tênues de deformação, desenvolvendo foliação incipiente formada pelo estiramento de quartzo e orientação de biotita, além de porções com texturas magmáticas preservadas. Correspondem aos ortognaisses tonalíticos e tonalitos tipo "Serra do Dondó" e "Fazenda das Almas" de Szabó (1989).

$\mathrm{Na}$ porção noroeste exibem textura hipoabissal, porfirítica, denotada por fenocristais euédricos a subédricos de plagioclásio, dispersos de forma aleatória em matriz microfanerítica a afanítica (Fig. 4C). Na parte sudoeste mostram textura magmática holocristalina, subédrica, equigranular, com agregados máficos contendo hornblenda e biotita. Apesar da natureza intrusiva destes corpos no substrato ortognáissico não ser evidente em campo, esta relação pode ser percebida em função das suas características estruturais e texturais. Geralmente os metatonalitos mostram texturas isotrópicas em comparação com a anisotropia observada nos gnaisses. Além disso, a delimitação em mapa da área alcançada pelos blocos e matacões, define corpos circunscritos no interior dos ortognaisses.

Dentro deste domínio foram reconhecidas três fácies, subdivididas em função da quantidade de hornblenda e texturas presentes.

A primeira fácies possui textura granoblástica, inequigranular com granulometria fina a média ou granolepidoblástica, equigranular, de granulometria fina. Localmente ocorre textura magmática holocristalina, granular preservada, denotada por grãos euédricos a subédricos de plagioclásio. Sua mineralogia principal é constituída por plagioclásio, quartzo e hornblenda. O plagioclásio é anédrico a subédrico, com geminação obliterada pela formação de saussurita. Locais com texturas porfiríticas são comuns, com cristais de 0,5 até $4 \mathrm{~cm}$ imersos em matriz fina e muito alterada, contendo clorita, saussurita e epídoto. O quartzo possui extinção ondulante ocorrendo em quantidades inferiores a $20 \%$. A hornblenda exibe uma coloração parda e comportamento poiquilítico, englobando apatitas, frequentemente desenvolvendo biotita em suas bordas ou a partir de sua clivagem. Como acessórios podem ser observados zircão, titanita, apatita e opacos xenoblásticos. Como produtos secundários observam-se a saussurita, sericita e o epídoto.

A segunda fácies possui textura granoblástica a granonematoblástica, inequigranular, com granulometria fina a grossa. O teor hornblenda é igual ou superior a $2 \%$, maior que nas outras fácies. Sua mineralogia principal é dada por plagioclásio, quartzo e hornblenda. O plagioclásio mostra geminação eventualmente obscurecida pela saussurita. Seu hábito é anédrico, possuindo gotículas de k-feldspato e pequenos cristais euédricos de epídoto e mica branca associados. O quartzo é anédrico e intersticial. A hornblenda apresenta-se parcialmente alterada, com cristais de coloração verde oliva que retrogradam para actinolita e clorita (Fig. 4D), ocasionalmente formando pseudomorfos. Como acessórios são observados a apatita, o zircão e opacos anédricos associados aos anfibólios. Esta fácies apresenta porções intensamente epidotizadas, principalmente em áreas afetadas por fraturas e microfalhas.

Tonalitos com textura magmática bem preservada formam a terceira fácies. Possui textura equigranular, holocristalina, hipidiomórfica, de granulometria grossa e inúmeros agregados máficos formados por anfibólio, biotita e opacos. Dois tipos de plagioclásio aparecem nesta rocha: um apresenta-se subédrico e bastante saussuritizado e outro subédrico a anédrico bem preservado. O quartzo é anédrico e intersticial. A biotita pode ser subédrica a anédrica ou se desenvolver a partir do anfibólio. A hornblenda apresenta textura relíquiar, com superfícies corroídas, retrogradando a biotita e clorita. Como minerais acessórios observam-se apatita, titanita, zircão e opacos anédricos.

\section{GRANITO CÓRREGO DO SAPATEIRO O Granito} Córrego do Sapateiro aflora na porção centro norte da área, formando colinas e morros com superfície rugosa, com blocos e matacões dispersos.

É um leucogranito de coloração levemente rosada e uma tênue foliação denotada pela orientação de biotita. Sua assembleia mineralógica principal é composta por quartzo, plagioclásio, microclina rósea e biotita.

Ao se decompor forma solo de coloração alaranjada clara, com vegetação rala e pobre, permitindo delimitar sua área de abrangência. Sua ocorrência na região não havia sido mapeada até então. 
Ao microscópio apresenta-se como uma rocha inequigranular, de granulação fina a grossa, holocristalina, localmente exibindo texturas poiquilítica e mirmequítica (Fig. 4E).

Sua mineralogia principal é dada por microclina, quartzo, plagioclásio e biotita. O quartzo é anédrico, intersticial, com extinção ondulante ou formando subgrãos nas bordas. A microclina é subédrica a anédrica, micropertítica. São observadas duas gerações de plagioclásio: a primeira subédrica, com grau de saussuritização acentuado, ocasionalmente geminado. A segunda geração é mais preservada, podendo sobrecrescer no entorno da primeira. Desenvolvem textura mirmequítica nos contatos com a microclina. A biotita é subédrica, em quantidades ínfimas, menores que 3\%. Desenvolvem clorita a partir de suas bordas e clivagem. Observam-se dois tipos de clorita, uma de coloração verde-oliva, mais férrica, e outra de coloração parda, menos abundante. Como minerais acessórios observam-se zircão e apatita.Sericita e saussurita são os produtos secundários mais comuns, desenvolvendo-se a partir de planos de clivagem ou fraturas na biotita e plagioclásio.

GRANITO ITAPIXÉ Aflora na extremidade nordeste da área, próximo ao alto curso do Ribeirão do Itapixé, a noroeste do vilarejo do Mandembo. Trata-se de um granito homogêneo, predominantemente equigranular de coloração acinzentada e tênue foliação paralela às bordas da intrusão, provavelmente de natureza magmática.Sua assembleia mineralógica é composta por quartzo, álcali-feldspato, plagioclásio e biotita de granulação fina.Este granito ocorre sob a forma de diques com espessura aparente de até oito metros, direção geral NW-SE, evidenciados frequentemente pela disposição de lajes e blocos orientados sobre o terreno. Encaixa-se ao longo de fraturas subparalelas ao trend observado para os diques máficos, mantendo contato abrupto com a encaixante.

Ao microscópio exibe textura holocristalina, leucocrática, equigranular, de granulação fina, com tênue deformação e foliação de fluxo dada pela orientação da biotita e pela disposição subparalela de cristais subédricos de feldspatos (Fig. 4F).

Sua mineralogia principal é constituída por microclina, plagioclásio, quartzo e biotita. A microclina é anédrica, micropertítica, algumas vezes com geminação pouco visível. Em geral apresenta-se bem preservada raramente sofrendo alteração para sericita. O plagioclásio é subédrico, apresentando sempre algum grau de saussuritização e com geminação parcialmente apagada. O quartzo é anédrico, intersticial, ocasionalmente estirado, podendo exibir extinção ondulante.Como minerais acessórios observam-se titanita, apatita, minerais opacos e zircão. Epídoto é raro e ocorre associado a carbonato secundário.

Apesar de possuir uma leve deformação, evidenciada pelo estiramento e extinção ondulante de alguns grãos de quartzo e contatos tríplices entre grãos, a disposição dos cristais de feldspatos e biotita, paralela às bordas da intrusão, sugere que esta foliação tem origem no fluxo do magma no interior do conduto.

\section{LITOGEOQUÍMICA DO COMPLEXO CAMPOS GERAIS E GRANITOIDES INTRUSIVOS ASSOCIADOS}

\section{Complexo Campos Gerais}

ASPECTOS LITOGEOQUÍMICOS GERAIS O Ortognaisse Campos Gerais apresenta teores de $\mathrm{SiO}_{2}$ entre 64,3 e $75,1 \%$, com empobrecimento em $\mathrm{Ni}, \mathrm{Cr}$ e baixo \#Mg $(<20 \mathrm{ppm} ;<20 \mathrm{ppm} ; 0,06$ a 0,29 , respectivamente). A razão $\mathrm{K}_{2} \mathrm{O} / \mathrm{Na}_{2} \mathrm{O}$ varia de 0,21 a 1,15 e o $\mathrm{Na}_{2} \mathrm{O}$ entre 3,9 e 5,5\% (Tab. 1). Possui quartzo e hiperstênio normativo, com teores de ortoclásio normativo entre 6,81 e $28,2 \%$, albita normativa entre 33,2 e $47,4 \%$ e anortita normativa entre 5,6 e 18,9\%. Em geral, o corindon normativo é inferior a $1 \%$. No Ortognaisse Mandembo, os teores de $\mathrm{SiO}_{2}$ variam de 71 a 77,2\%, com empobrecimento em Ni, Cr e baixo \#Mg $(<20 \mathrm{ppm}$; $<20$ ppm; 0,06 a 0,2, respectivamente). A razão $\mathrm{K}_{2} \mathrm{O} / \mathrm{Na}_{2} \mathrm{O}$ varia de 0,6 a 1,45 e o $\mathrm{Na}_{2} \mathrm{O}$ entre 3,1 a $4,0 \%$. Apresenta quartzo e hiperstênio normativo, com teores de ortoclásio normativo entre 11,7 a $30,35 \%$, albita normativa de 26,8 a $33,8 \%$ e anortita normativa de 3,7 a $8,9 \%$. O corindon normativo é inferior a $1 \%$.

\section{CLASSIFICAÇÃO QUÍMICA DOS LITOTIPOS}

Em termos de elementos maiores e elementos menos móveis como $\mathrm{Zr}$, os protólitos do Ortognaisse Campos Gerais são classificados como granodioritos e granitos (Lê Maitre 1989, Winchester \& Floyd 1977) (Figs. 5A e B), embora quando são considerados os parâmetros R1 versus R2 (De La Roche et al. 1980), um membro deste grupo apresenta-se como tonalito (Fig. 5C). 

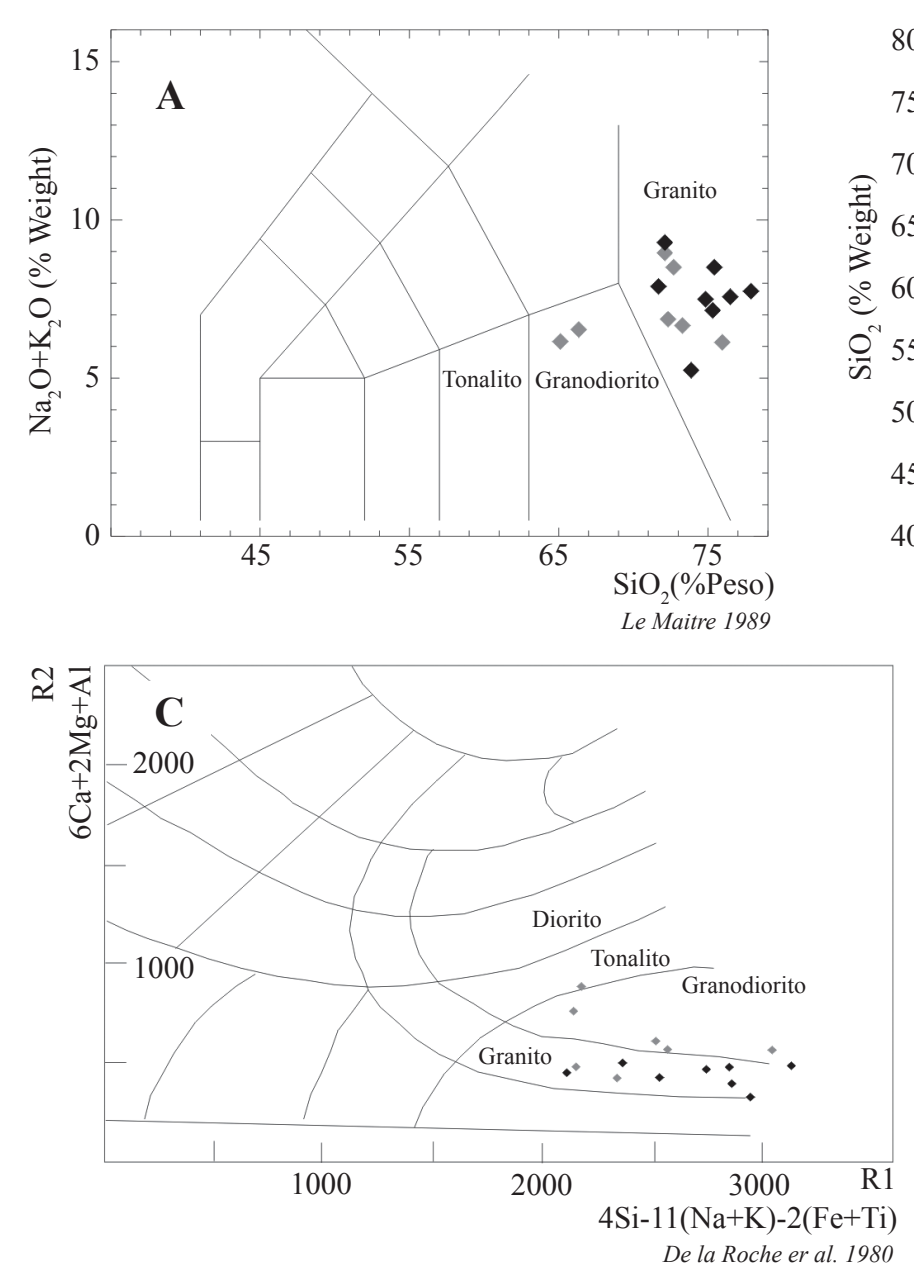
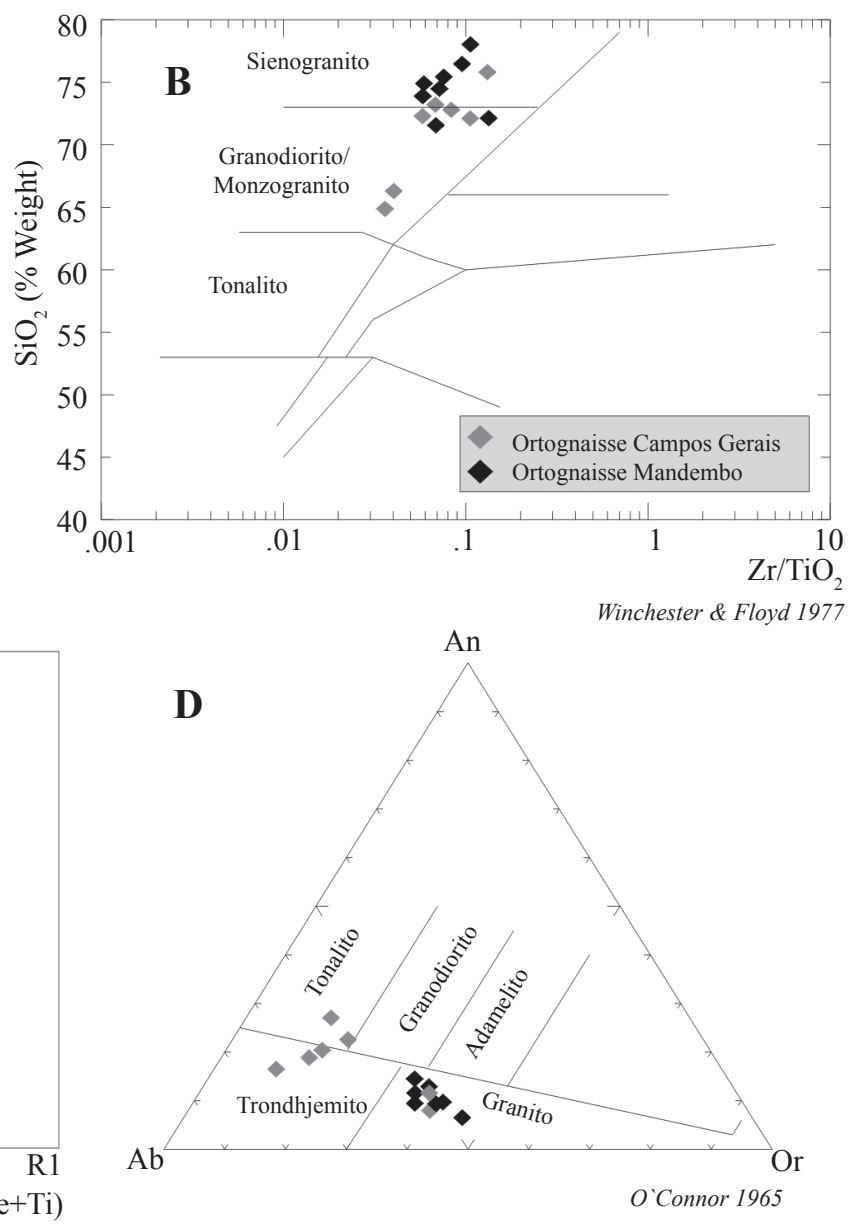

Figura 5 - Diagramas de classificação litogeoquímica para os ortognaisses do Complexo Campos Gerais.

Os protólitos do Ortognaisse Mandembo classificam-se predominantemente como granitos (Lê Maitre 1989, De La Roche et al. 1980), embora, na classificação de Winchester \& Floyd (1977), duas amostras apresentem composição granodiorítica.

Em relação à composição normativa, o diagrama triangular Ab, An e Or de O'Connor (1965) separa o conjunto em uma série de tonalitos e trondhjemitos e granitos (Ortognaisse Campos Gerais). No outro grupo (Ortognaisse Mandembo), a maioria das amostras é classificada como granito, com um membro trondhjemítico (Fig. 5D).

\section{DISCRIMINAÇÃO DE SÉRIES MAGMÁTICAS Os} ortognaisses Campos Gerais e Mandembo apresentam assinatura geoquímica subalcalina, calcioalcalina (Irvine \& Baragaer 1971) (Fig. 6A e B).

$\mathrm{O}$ diagrama triangular que relaciona $\mathrm{K}_{2} \mathrm{O}$, $\mathrm{Na}_{2} \mathrm{O}$ e $\mathrm{CaO}$ (Barker \& Arth 1976) sugere que o Ortognaisse Campos Gerais pode estar relacionado a uma série trondhjemítica, enquanto o Ortognaisse Mandembo a uma série calcioalcalina (Fig. 6C).
Do ponto de vista da saturação em alumina, o Ortognaisse Campos Gerais é fracamente peraluminoso a metaluminoso, enquanto que as amostras do Ortognaisse Mandembo são exclusivamente peraluminosas (Maniar \& Piccoli 1989) (Fig. 6D).

Em relação ao teor de $\mathrm{K}_{2} \mathrm{O}$, o Ortognaisse Campos Gerais comporta-se predominantemente como rocha da série médio-K. O Ortognaisse Mandembo é da série de alto-K (Le Maitre 1989) (Fig. 6E).

PETROGENESE A análise dos diagramas tipo Harker é uma importante ferramenta na confirmação de suítes magmáticas relacionadas aos protólitos pertencentes aos ortognaisses. No entanto, uma abordagem prévia considerando alguns parâmetros relacionados a elementos incompatíveis e compatíveis foi necessária para se verificar o grau de contaminação (assimilação) de crosta continental e (ou) a participação de manto litosférico metasomatizado na gênese dos magmas. Valores de razões $\mathrm{La}$ e $\mathrm{Nb}$ normalizados para condrito $-(\mathrm{La} / \mathrm{Nb})_{\mathrm{N}}>1-$ indicam que a 

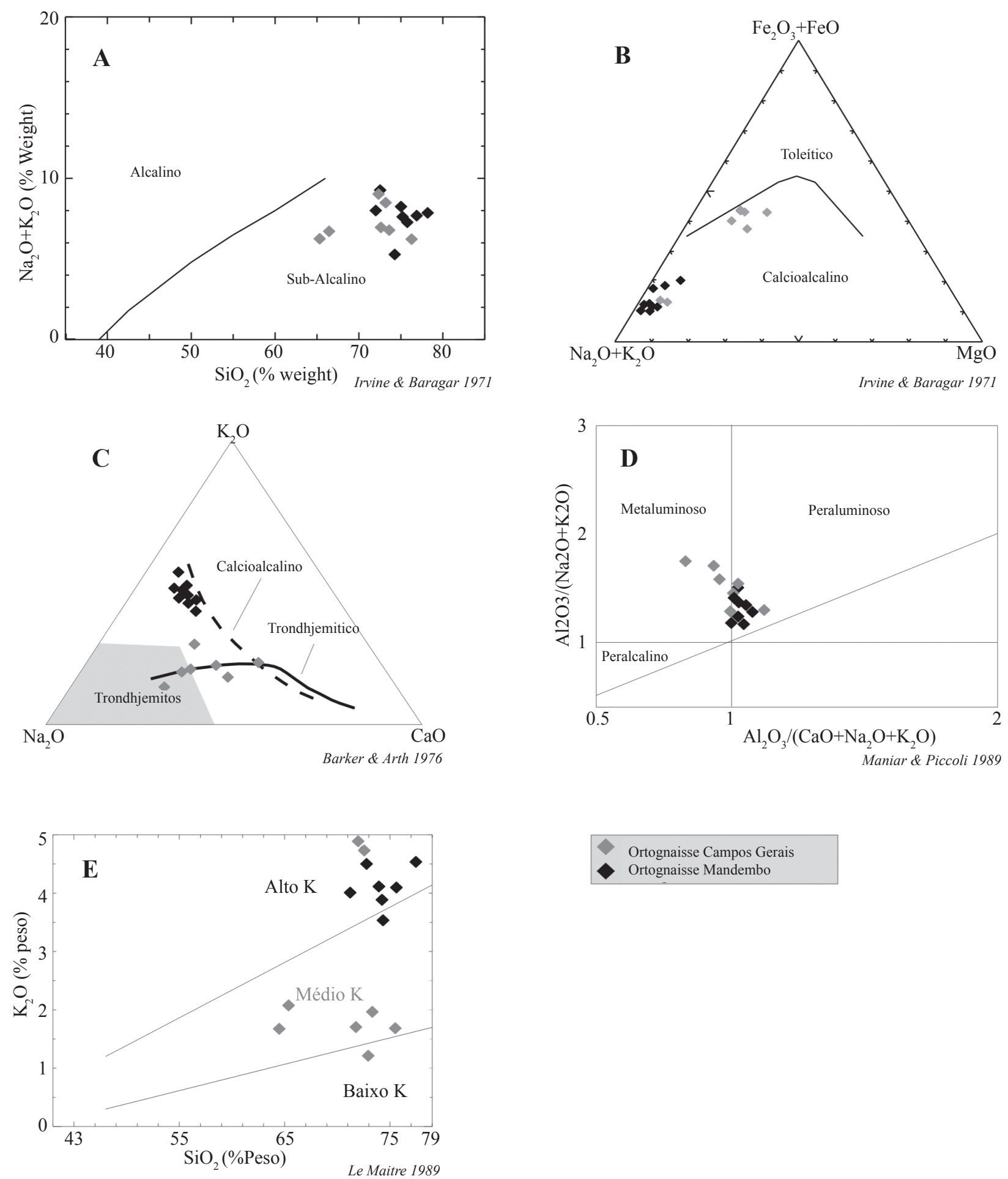

Figura 6 - Caracterização de séries magmáticas para os protólitos do Complexo Campos Gerais.

fonte magmática ou o processo de diferenciação teve participação do manto litosférico subcontinental e/ou assimilação de crosta continental, enquanto que razões $\mathrm{La} / \mathrm{Nb}_{\mathrm{N}}<1$ indicam participação do manto litosférico não contaminado ou do manto astenosférico (Thompson et al. 1984). As amostras apresentam razões $\mathrm{La} / \mathrm{Nb}_{\mathrm{N}}$ muito superiores à unidade (Tab. 1), indicando a possível participação da cunha mantélica metassomatizada ou crosta continental na gênese e evolução magmática.

O método dos mínimos quadrados foi aplicado nos diagramas Harker para os dois ortognaisses, a fim de indicar o tipo de curva que melhor se adequou à distribuição das amostras e à regressão na população de dados. Desta forma, os diagramas bivariantes para elementos maiores, alguns elementos 
traços incompatíveis (LILE) como $\mathrm{Rb}, \mathrm{Sr}, \mathrm{Ba}$, elementos fracamente incompatíveis (HFSE) como $\mathrm{Zr}$ e elementos compatíveis como $\mathrm{Nb}$, evidenciaram para os dois grupos coeficientes de correlação polinomial (R) mais elevado que os obtidos para as correlações lineares.

No Ortognaisse Campos Gerais, elementos como Al, Fe, Mn, Ca, Na, P, Ti e Sr, apresentaram boa correlação e níveis de significância acima de 95\% (Tab. 3). Para o Ortognaisse Mandembo as melhores correlações foram obtidas com o $\mathrm{Al}, \mathrm{Fe}, \mathrm{Mn}, \mathrm{Mg}$, $\mathrm{Na}, \mathrm{P}$ e Sr. Estes dados indicam que os processos de evolução magmática envolveram em algum momento mudança nas assembleias mineralógicas relacionadas a estes elementos, durante processos de cristalização fracionada e/ou fusão parcial. Os demais elementos utilizados demonstraram dispersão e correlações pouco significativas.

Em geral os diagramas tipo Harker (Fig. 7), evidenciaram correlação negativa para a maioria dos elementos maiores, com exceção $\mathrm{Na}_{2} \mathrm{O}$ e do $\mathrm{K}_{2}$ Oque mostraram correlações positivas para o Ortognaisse Campos Gerais e Ortognaisse Mandembo, respectivamente, comprovando suas afinidades trondhjemítica e de Alto-K. A dispersão encontrada para elementos mais incompatíveis como $\mathrm{K}, \mathrm{Na}, \mathrm{Rb}, \mathrm{Ba}, \mathrm{Zr}$ parece estar relacionada à assimilação de crosta. $\mathrm{K}$, $\mathrm{Na}, \mathrm{Rb}, \mathrm{Ba}$, por formarem íons de grande raio iônico ou possuírem baixa carga iônica, costumam escapar com facilidade das estruturas minerais, concentrando-se no líquido magmático recém-formado ou em fases fluidas. Além disso, são extremamente móveis em processos metassomáticos e intempéricos, mascarando suas concentrações originais. O problema ao se trabalhar com estes elementos em arcos magmáticos e margens ativas é saber exatamente qual a concentração original no magma e qual é a parcela de contaminação oriunda do metassomatismo litosférico por fluidos vindos de litosfera oceânica em subducção.

Variações na concentração e dispersão de elementos proporcionalmente mais compatíveis, ou seja, aqueles elementos que ficam fortemente presos às estruturas minerais, permanecendo nas fases cristalinas fracionantes do magma ou no resíduo de fusão parcial, podem indicar assimilação crustal.

Para o $\mathrm{Nb}$, assimilação de porções crustais contendo rutilo, ilmenita ou hornblenda pode causar variações no teor deste elemento.

Para o $\mathrm{Sr}$, sua correlação com a $\mathrm{SiO}_{2}$ em ambos ortognaisses, mostrou um comportamento semelhante ao do $\mathrm{Ca}$, evidenciando variações na quantidade de plagioclásio presente.

No Ortognaisse Campos Gerais, a análise de elementos terras-raras normalizados pela abundância em condrito (Boyton 1984) mostra uma conformação côncava, com fracionamento de ETR médios, ausência de anomalia negativa de Eu, enriquecimento em ETR leves e razões $(\mathrm{La} / \mathrm{Yb})_{\mathrm{N}}$ variando de 12 a até 102 (Fig. 8A). Para o Ortognaisse Mandembo, o padrão de ETR normalizados pela abundância em condrito mostra anomalias de Eu e o empobrecimento em ETR médios (Fig. 8B). Além disso, as amostras

Tabela 3 - Coeficientes de correlação e significância para amostras do Complexo Campos Gerais e Metagranitoide Grão Mogol

\begin{tabular}{lccccccccc}
\hline \multicolumn{7}{c}{ Ortognaisses } \\
\hline & Linear & Polinomial & Significancia (\%) & Linear & Polinomial & Significância (\%) & Linear & Polinomial & Significância(\%) \\
\hline $\mathrm{Al}_{2} \mathrm{O}_{3}$ & 0,87 & 0,91 & 99 & 0,96 & 0,96 & 99,9 & 0,84 & 0,87 & 99 \\
\hline $\mathrm{Fe}_{2} \mathrm{O}_{3}$ & 0,99 & 0,99 & 99,9 & 0,88 & 0,98 & 99,9 & 0,71 & 0,87 & 99 \\
\hline $\mathrm{MnO}$ & 0,95 & 0,96 & 99,9 & 0,88 & 0,96 & 99,9 & 0,82 & 0,94 & 99,9 \\
\hline $\mathrm{MgO}$ & 0,97 & 0,97 & 99,9 & 0,61 & 0,61 & $80-90$ & 0,4 & 0,63 & 90 \\
\hline $\mathrm{CaO}$ & 0,90 & 0,90 & 99 & 0,69 & 0,82 & $95-99$ & 0,79 & 0,79 & 95 \\
\hline $\mathrm{Na}_{2} \mathrm{O}$ & 0,38 & 0,44 & $<80$ & 0,89 & 0,90 & 99 & 0,33 & 0,41 & 80 \\
\hline $\mathrm{K}_{2} \mathrm{O}$ & 0,10 & 0,11 & $<80$ & 0,06 & 0,49 & $<80$ & 0,26 & 0,28 & $<80$ \\
\hline $\mathrm{TiO} \mathrm{O}_{2}$ & 0,95 & 0,95 & 99,9 & 0,63 & 0,70 & $90-95$ & 0,86 & 0,90 & 99,9 \\
\hline $\mathrm{P}_{2} \mathrm{O}_{5}$ & 0,93 & 1,00 & 99,9 & 0,77 & 0,89 & 99 & 0,87 & 0,87 & 99 \\
\hline $\mathrm{Rb}$ & 0,31 & 0,61 & $80-90$ & 0,33 & 0,34 & $<80$ & 0,25 & 0,43 & $<80$ \\
\hline $\mathrm{Sr}$ & 0,70 & 0,92 & 99 & 0,86 & 0,90 & 99 & 0,36 & 0,74 & 95 \\
\hline $\mathrm{Ba}$ & 0,22 & 0,28 & $<80$ & 0,47 & 0,70 & $90-95$ & 0,16 & 0,57 & 90 \\
\hline $\mathrm{Zr}$ & 0,50 & 0,57 & 80 & 0,49 & 0,50 & $<80$ & 0,25 & 0,32 & $<80$ \\
\hline $\mathrm{Nb}$ & 0,65 & 0,83 & $95-99$ & 0,53 & 0,54 & $<80$ & 0,43 & 0,69 & $95-99$ \\
\hline
\end{tabular}



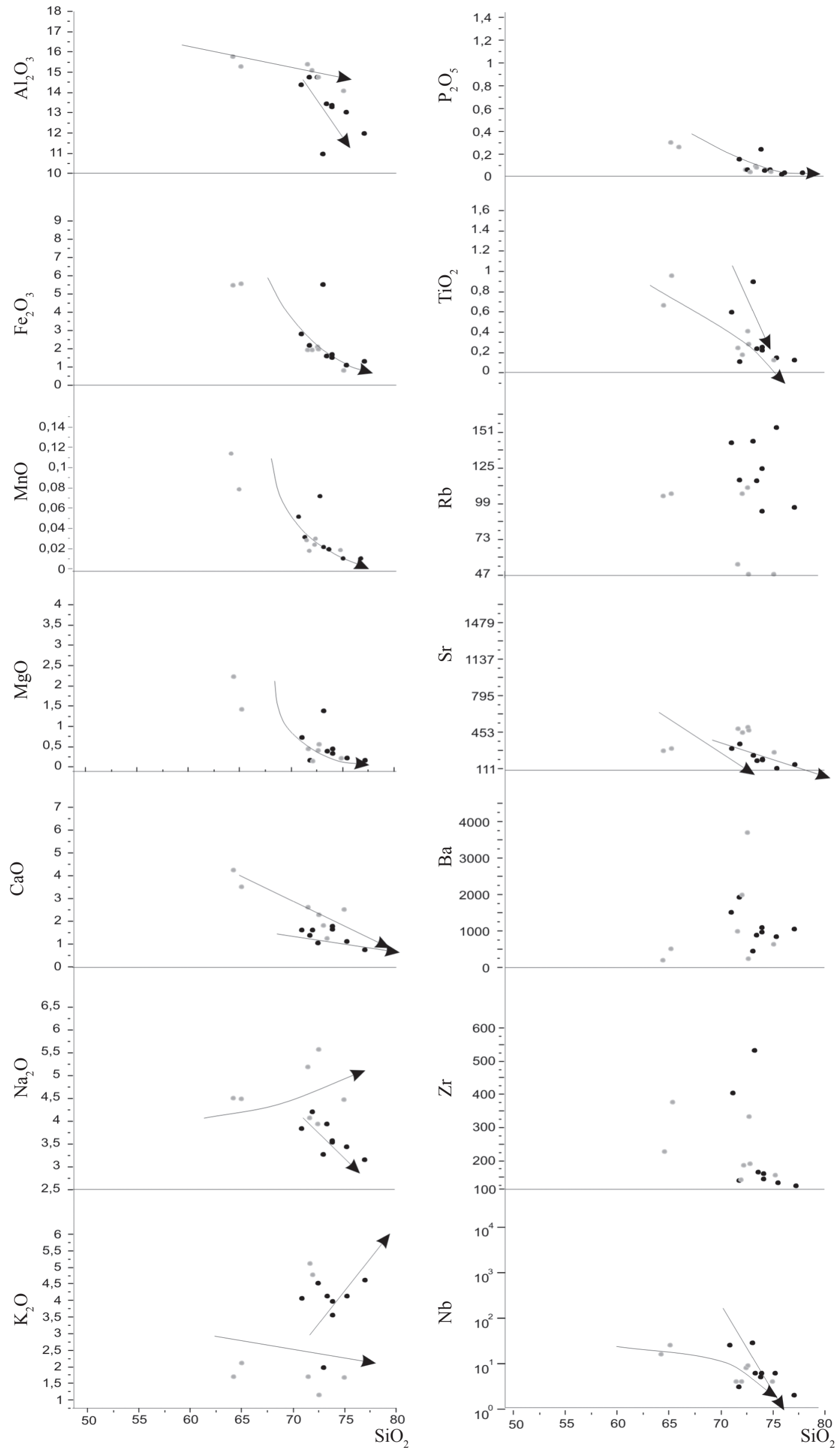

Figura 7 - Diagramas de variação tipo Harker para amostras do Complexo Campos Gerais. 

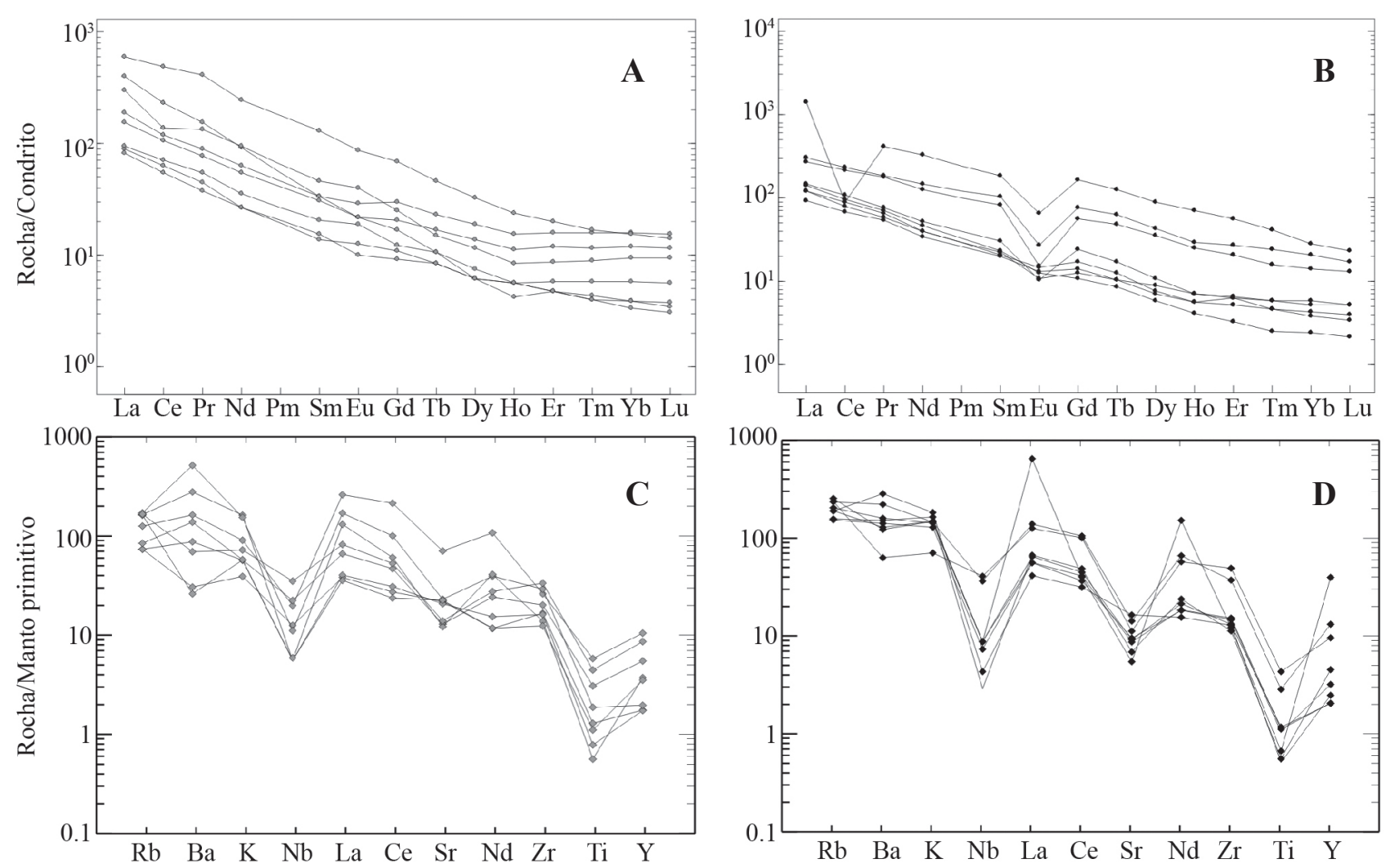

Figura 8 - Distribuição dos elementos terras raras normalizados para condrito (Boyton 1984) e diagramas multielementais normalizado pela abundância no manto primitivo (McDonnough et al. 1992) em amostras do Complexo Campos Gerais. (A e C) Ortognaisse Campos Gerais; (B e D) Ortognaisse Mandembo.

exibem pouco fracionamento de ETR pesados e razões $(\mathrm{La} / \mathrm{Yb})_{\mathrm{N}}$ de 14,4 a 49,7.

Os diagramas multielementais normalizados pela abundância em manto primitivo (McDonnough et al. 1992) mostraram que o Ortognaisse Campos Gerais apresenta anomalias negativas a fortemente positivas para $\mathrm{Ba}$, anomalias negativas de $\mathrm{Nb}$, Ti e anomalias negativas a fracamente positivas de Sr (Fig. 8C). Já o Ortognaisse Mandembo apresenta anomalias negativas a levemente positivas para $\mathrm{Ba}$, anomalias negativas de $\mathrm{Ti}$ e anomalias negativas mais intensas que do Ortognaisse Campos Gerais nos conteúdos de $\mathrm{Nb}$ e $\mathrm{Sr}$ (Fig. 8D).

Os parâmetros $\varepsilon N d$ levemente negativos encontrados nos ortognaisses (Tab. 2) sugerem a alguma participação e assimilação de crosta continental nos processos de diferenciação magmática.

\section{Granitoides intrusivos}

ASPECTOS LITOGEOQUIMMICOS GERAIS Em termos químicos gerais, o Metagranitoide Grão Mogol apresenta teor de $\mathrm{SiO}_{2}$ de 69 a 76\%, sendo francamente empobrecido em $\mathrm{Ni}$ e $\mathrm{Cr}$ e com baixo \#Mg
( $<20$ ppm; $<20$ ppm; 0,21 a 0,38 , respectivamente). A razão $\mathrm{K}_{2} \mathrm{O} / \mathrm{Na}_{2} \mathrm{O}$ próxima ou superior à unidade indica um conjunto de rochas predominantemente relacionadas a séries potássicas arqueanas (De Wit 1998). Apresenta quartzo e hiperstênio normativo, com teores de ortoclásio normativo entre 13,8 a $38,2 \%$, albita normativa de 23,1 a $42,1 \%$ e anortita normativa de 2,6 a $10,7 \%$. O corindon normativo em geral é inferior a $1 \%$, com uma amostra apresentando valor de 2,5\% (Tab. 1).

$\mathrm{O}$ Metatonalito apresenta teores de $\mathrm{SiO}_{2}$ entre 65 e $72 \%$, com empobrecimento em $\mathrm{Ni}, \mathrm{Cr}$ e baixo \#Mg (<20 ppm; $<20$ ppm; 0,18 e 0,30 respectivamente) e razão $\mathrm{K}_{2} \mathrm{O} / \mathrm{Na}_{2} \mathrm{O}$ entre 0,3 e 0,52. Apresenta quartzo e hiperstênio normativo, com teores de ortoclásio normativo entre 9,77 a 13,9\%, albita normativa de 37,8 a $45,8 \%$ e anortita normativa de 10,3 a $15,4 \%$. O corindon normativo em geral é inferior a $1 \%$, com três amostras apresentando valores entre 1,5 e 2,8\%.

O granito Córrego do Sapateiro apresenta $75 \%$ de $\mathrm{SiO}_{2}$, empobrecimento em $\mathrm{Ni}, \mathrm{Cr}$, baixo $\# \mathrm{Mg}$ ( $<20$ ppm; $<20$ ppm; 0,12, respectivamente) e razão $\mathrm{K}_{2} \mathrm{O} / \mathrm{Na}_{2} \mathrm{O}$ de 1,16 . Apresenta quartzo e hiperstênio normativo, $26,3 \%$ de ortoclásio normativo, $32,3 \%$ de 

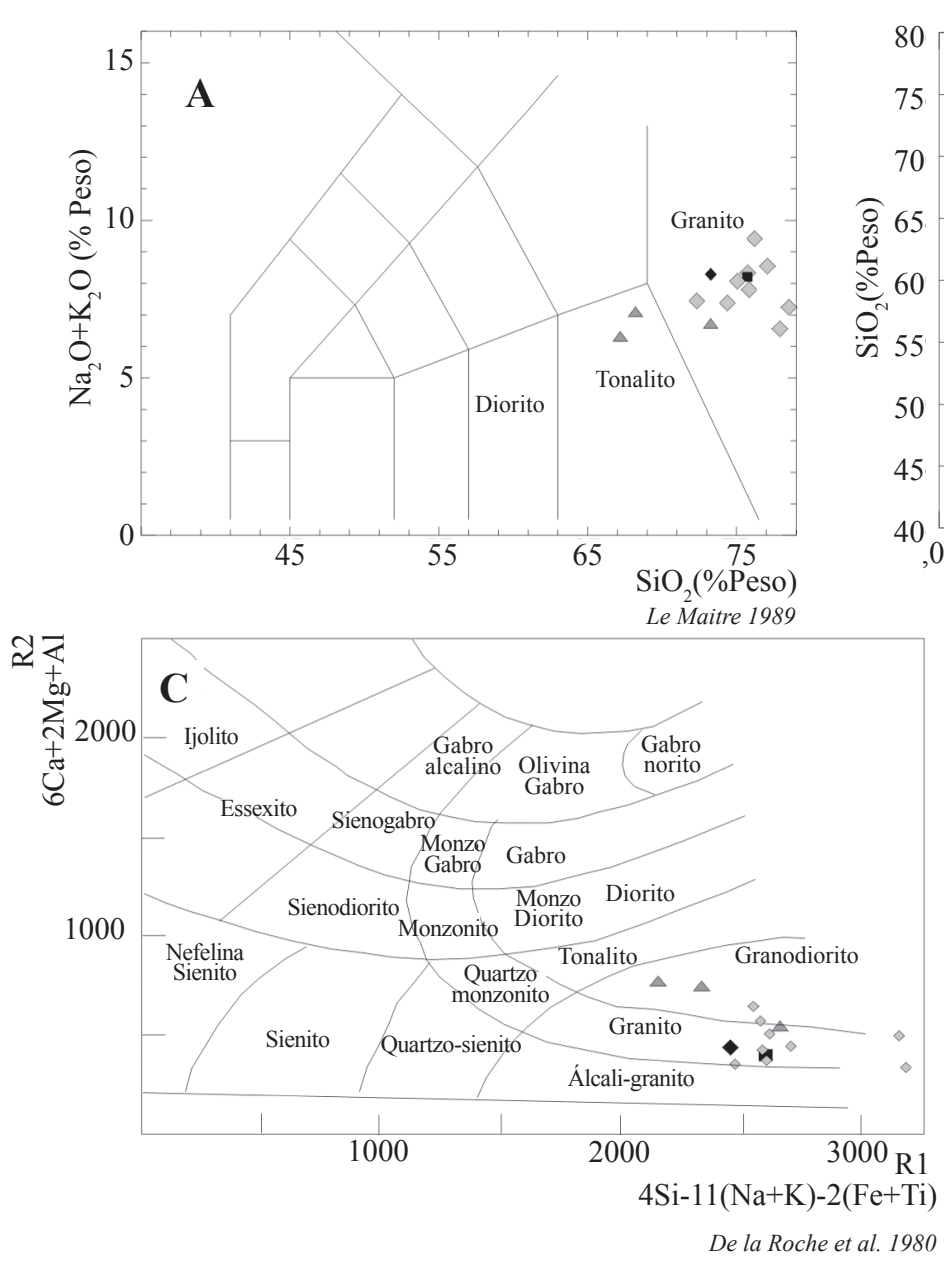
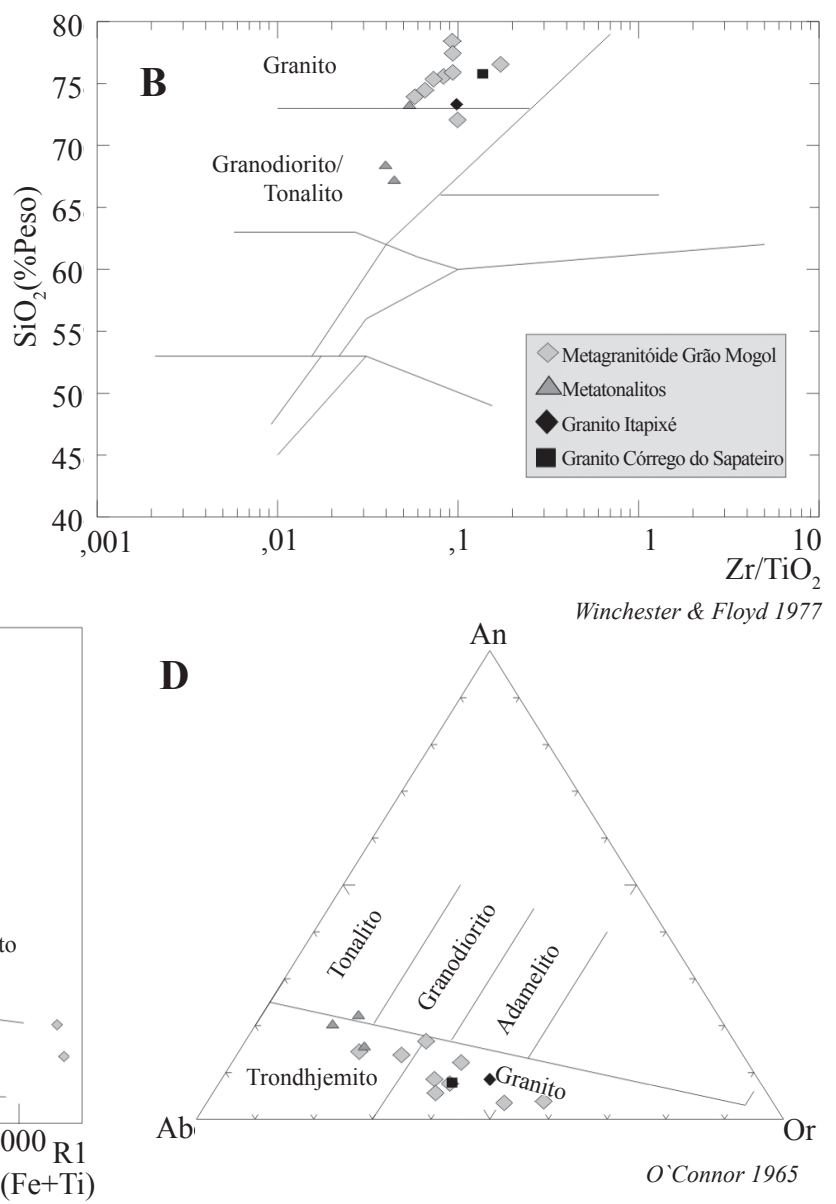

Figura 9 - Diagramas de classificação litogeoquímica para os granitoides intrusivos no Complexo Campos Gerais na região ao sul de Alpinópolis.

albita normativa e 5,78\% de anortita normativa. O corindon normativo é inferior a $1 \%$.

O Granito Itapixé apresenta $72 \%$ de $\mathrm{SiO}_{2}$, empobrecimento em $\mathrm{Ni}, \mathrm{Cr}$, baixo \#Mg $(<20 \mathrm{ppm}$; $<20$ ppm; 0,18, respectivamente) e razão $\mathrm{K}_{2} \mathrm{O} / \mathrm{Na}_{2} \mathrm{O}$ de 1,54. Apresenta quartzo e hiperstênio normativo, $30 \%$ de ortoclásio normativo, $27,8 \%$ de albita normativa e $6,12 \%$ de anortita normativa. O corindon normativo é inferior a $1 \%$.

\section{CLASSIFICAÇÃODOSLITOTIPOSO Metagranitoide} Grão Mogol é proveniente do metamorfismo de protólitos essencialmente graníticos com raros membros granodioríticos (Lê Maitre 1989, Winchester \& Floyd 1977, De La Roche et al. 1980) (Fig. 9A). No diagrama para feldspatos normativos (O'Connor 1965), este metagranitoide mostra ser gerado a partir de protólitos trondhjemíticos, possuindo, entretanto, a maior parte das amostras no campo dos granitos (Fig. 9D).

Os metatonalitos, como esperado, plotam no campo dos tonalitos (Lê Maitre 1989), com uma amostra no campo dos granitos (Fig. 9A). O diagrama que relaciona $\mathrm{Zr} / \mathrm{TiO}_{2} \mathrm{X} \mathrm{SiO}_{2}$ de Winchester \& Floyd (1977) classifica as amostras de forma semelhante, posicionando duas amostras no campo dos tonalitos e granodioritos e uma amostra na interface com os granitos (Fig. 8B). No diagrama R1 versus R2 (De La Roche et al. 1980), os metatonalitos classificam-se como granodioritos (Fig. 8C). O diagrama normativo triangular que considera $\mathrm{Ab}, \mathrm{An}$ e Or de O'Connor (1965) discrimina os litotipos como tonalitos e trondhjemitos (Fig. 9D).

Os granitos Córrego do Sapateiro e o leucogranito Itapixé plotam no campo dos granitos em todos os diagramas (Lê Maitre,1989, Winchester \& Floyd 1977, De La Roche et al. 1980, O’Connor 1965).

DISCRIMINAÇÃO DE SÉRIES O Metagranitoide Grão Mogol apresenta assinatura subalcalina, calcioalcalina (Irvine \& Barangar 1971, Barker \& Arth 1976), moderadamente a fracamente peraluminosa, de médio a alto-K (Fig. 10). 
Os metatonalinos apresentam assinatura geoquímica subalcalina, calcioalcalina (Irvine \& Baranger 1971), trondhjemítica (Barker \& Arth 1976), peraluminosa a metaluminosa (Maniar \& Piccoli,1989), de médio-K (Lê Maitre 1989).

Os granitos Córrego do Sapateiro e Itapixé apresentam assinatura geoquímica subalcalina, calcioalcalina (Irvine \& Baranger 1971; Barker \& Arth
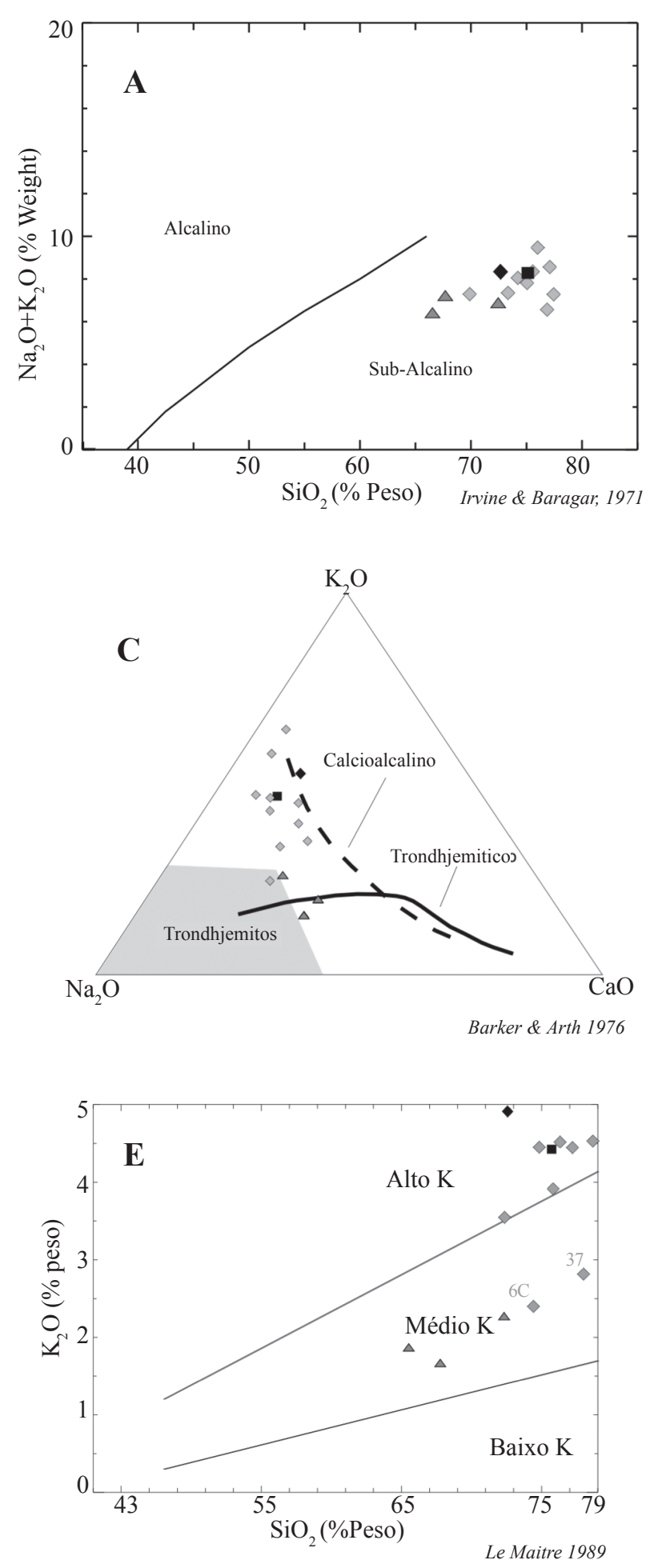

1976), peraluminosa (Maniar \& Piccoli 1989), com forte enriquecimento em potássio (Lê Maitre 1989).

\section{PETROGENESE}

Metagranitoide Grão Mogol Nos diagramas tipo Harker, a prevalência de valores superiores para o coeficiente de correlação polinomial sobre o linear indicou a existência de processos de fusão parcial ou cristalização
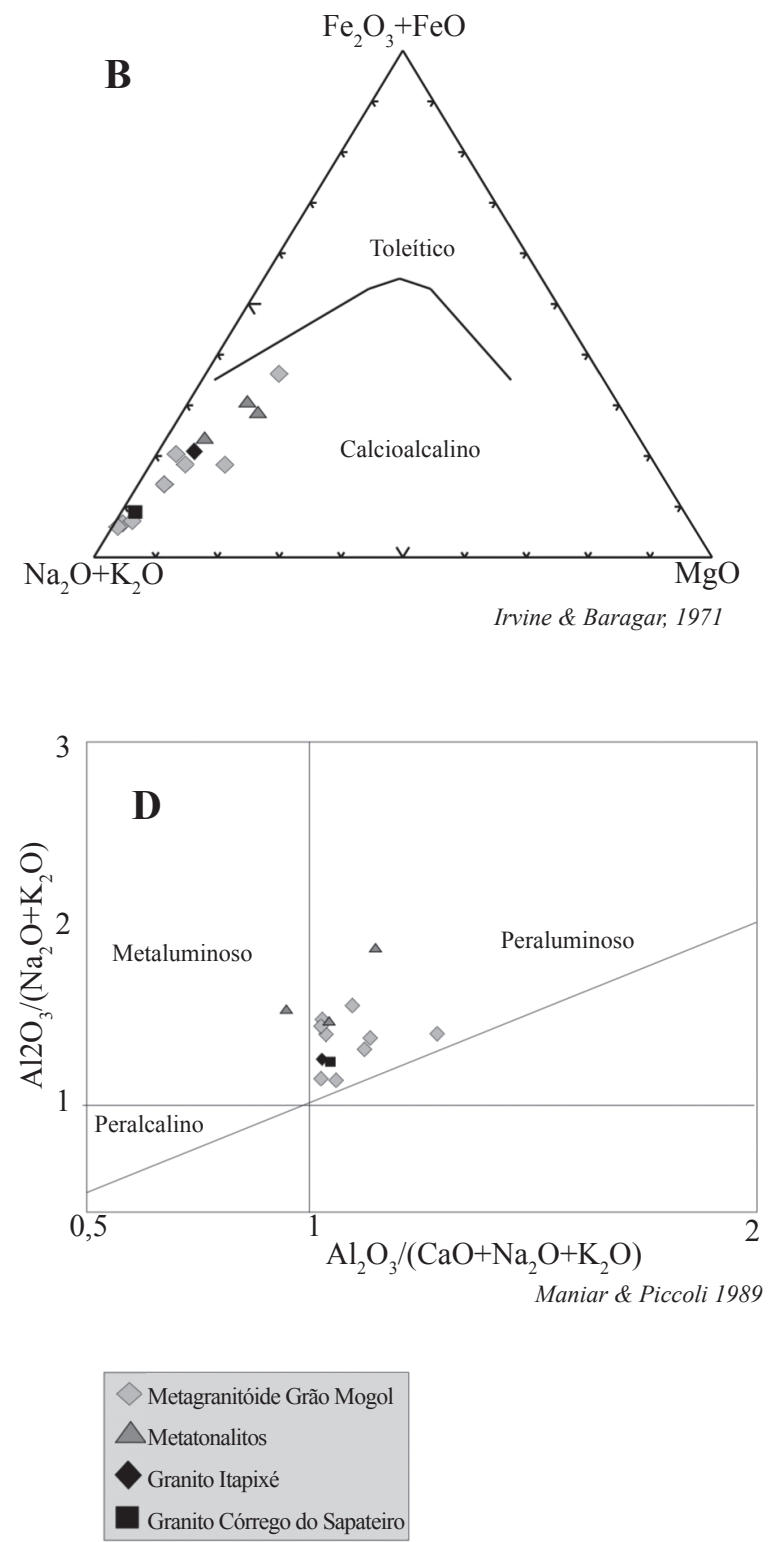

Figura 10-Caracterização de séries magmáticas para os granitoides intrusivos no Complexo Campos Gerais na região ao sul de Alpinópolis. 
fracionada com mudança da assembleia fracionante, na gênese dos magmas formadores dos protólitos (Tab. 3).

Em geral, todos os elementos demonstraram correlação negativa com aumento da $\mathrm{SiO}_{2}$, com exceção do $\mathrm{K}_{2} \mathrm{O}$ e Ba. Para íns litófilos de raio grande (LILE), foram observadas baixas correlações com $\mathrm{SiO}_{2}$ (Fig. 11).

A dispersão encontrada para LILE como $\mathrm{Rb}$, $\mathrm{Ba}, \mathrm{Na}_{2} \mathrm{O}$ e $\mathrm{K}_{2} \mathrm{O}$, a exemplo do que acontece no Ortognaisse Campos Gerais, parece estar relacionada à assimilação crustal ou algum evento metassomático, fato sugerido a partir da observação de epídoto próximo às zonas de cisalhamento.Os padrões de terras raras normalizados pela abundância em condrito (Boyton 1984) mostraram enriquecimento em terras raras leves e terras raras pesados não fracionados, $\mathrm{O}$ que sugere fonte sem granada ou anfibólio (Fig. 12A). Anomalias negativas e positivas de Eu são observadas nos membros mais primitivos e mais evoluídos da série, respectivamente, podendo ser um indicativo de variações no conteúdo de plagioclásio ou participação de fases como apatita e allanita nos membros com anomalia positiva. As razões $(\mathrm{Gd} / \mathrm{Yb})_{\mathrm{N}}$ próximas a $1 \mathrm{com}$ provam a inexistência de fracionamento de ETR pesados. Os diagramas multielementais normalizados pela abundância em manto primitivo (McDonnough et al. 1992), mostram que a série apresenta anomalias negativas de Nb, Sr e Ti (Fig. 12B).

Metatonalitos A análise de ETR, normalizados pela abundância em condrito (Boyton 1984), mostrou que estas rochas apresentam enriquecimento em ETR leves e empobrecimento em ETR pesados, com razão $(\mathrm{La} / \mathrm{Yb})_{\mathrm{N}}$ variando de 17,8 a 45,8 e ausência de anomalias negativas de Eu (Fig. 12C), padrão típico para magmas TTGs. Nos diagramas multielementais, normalizados para abundância de elementos em manto primitivo (McDonnough et al. 1992), estas rochas apresentam forte anomalia negativa de $\mathrm{Nb}$ e Ti e leves anomalias positivas de $\mathrm{Ba}$ (Fig. 12D).

A notação $\varepsilon_{\mathrm{Nd}}$ mostrou valores próximos a zero ou levemente negativos, indicando como fonte para os magmas o manto empobrecido ou MORB.

Granitos Córrego do Sapateiro e Itapixé $\mathrm{Na}$ análise de ETR normalizados pela abundância em condrito (Boyton 1984), o Granito Córrego do Sapateiro apresenta pronunciada anomalia de Ce e razão $(\mathrm{La} / \mathrm{Yb})_{\mathrm{N}}$ de 4,4 com uma leve anomalia de Eu. Os ETR pesados não são fracionados, apresentando leve convexidade, semelhante ao padrão para ETR pesados observados em MORB (Fig. 12E). O Granito Itapixé apresenta enriquecimento em ETR leves em relação ao Granito Córrego do Sapateiro, forte anomalia negativa de Eu e leve fracionamento em ETR pesados, com razão $(\mathrm{La} / \mathrm{Yb})_{\mathrm{N}}$ de 26,4 (Fig. 12E).

Nos diagramas multielementais normalizados pela abundância no manto primitivo (McDonnough et al. 1992), o Granito Córrego do Sapateiro exibe leve anomalia negativa de $\mathrm{Ba}$, seguida de forte anomalia negativa de $\mathrm{Nb}$ e $\mathrm{Ti}$ (Fig. 12F). O Granito Itapixé registra anomalias negativas de $\mathrm{Nb}, \mathrm{Sr}$ e $\mathrm{Ti}$ e ausência de anomalias no Ba (Fig. 12F).

DISCUSSÕES E CONCLUSÕES Os resultados litogeoquímicos com base em elementos maiores mostraram distinção clara entre os ortognaisses do Complexo Campo Gerais, cujos protólitos formam duas suítes distintas: uma de afinidade trondhjemítica (Ortognaisse Campos Gerais) e outra calcioalcalina (Ortognaisse Mandembo).

No Ortognaisse Campos Gerais, a presença de membros graníticos no diagrama de feldspatos normativos (O'Connor 1965) é incomum. Suítes TTG sofrem enriquecimento contínuo em $\mathrm{Na}$. Assim, é esperado que o magma subsaturado em $\mathrm{K}$ e enriquecido em $\mathrm{Na}$, forme albita e não ortoclásio, diminuindo substancialmente as chances de evolução de magmas graníticos a partir de magmas parentais trondhjemíticos. Desta forma, a explicação mais plausível para a existência de membros graníticos nos protólitos do Ortognaisse Campos Gerais é a assimilação de crosta félsica por magmas TTG.

O conjunto ortognáissico mostrou enriquecimento em ETR leves e LILE, sugerindo a contaminação do magma por fluidos, sedimentos oriundos da crosta oceânica em subducção ou assimilação e contaminação crustal. O empobrecimento ETR médios em ambos os ortognaisses indica como fonte de magma rochas contendo hornblenda e provavelmente granada. Prováveis fontes podem ser relacionadas a equivalentes metamorfisados de crosta oceânica, possivelmente granada anfibolito ou hornblenda eclogito, fato normalmente admitido para rochas arqueanas. $\mathrm{O}$ resíduo esperado para tais fontes é constituído por hornblenda, granada e pequenas quantidades de clinopiroxênio e plagioclásio, o que geraria o fracionamento dos ETR médios e pesados (Martin 1994). Valores $\varepsilon_{\mathrm{Nd}}$ negativos nos ortognaisses atestam a participação de crosta continental no processo, o que diminui a possibilidade de participação única e exclusiva da fusão de equivalentes metamorfisados de crosta oceânica. A ausência de anomalia negativa de Eu no Ortognaisse Campos 
Caio Vinícius Gabrig Turbay et al.
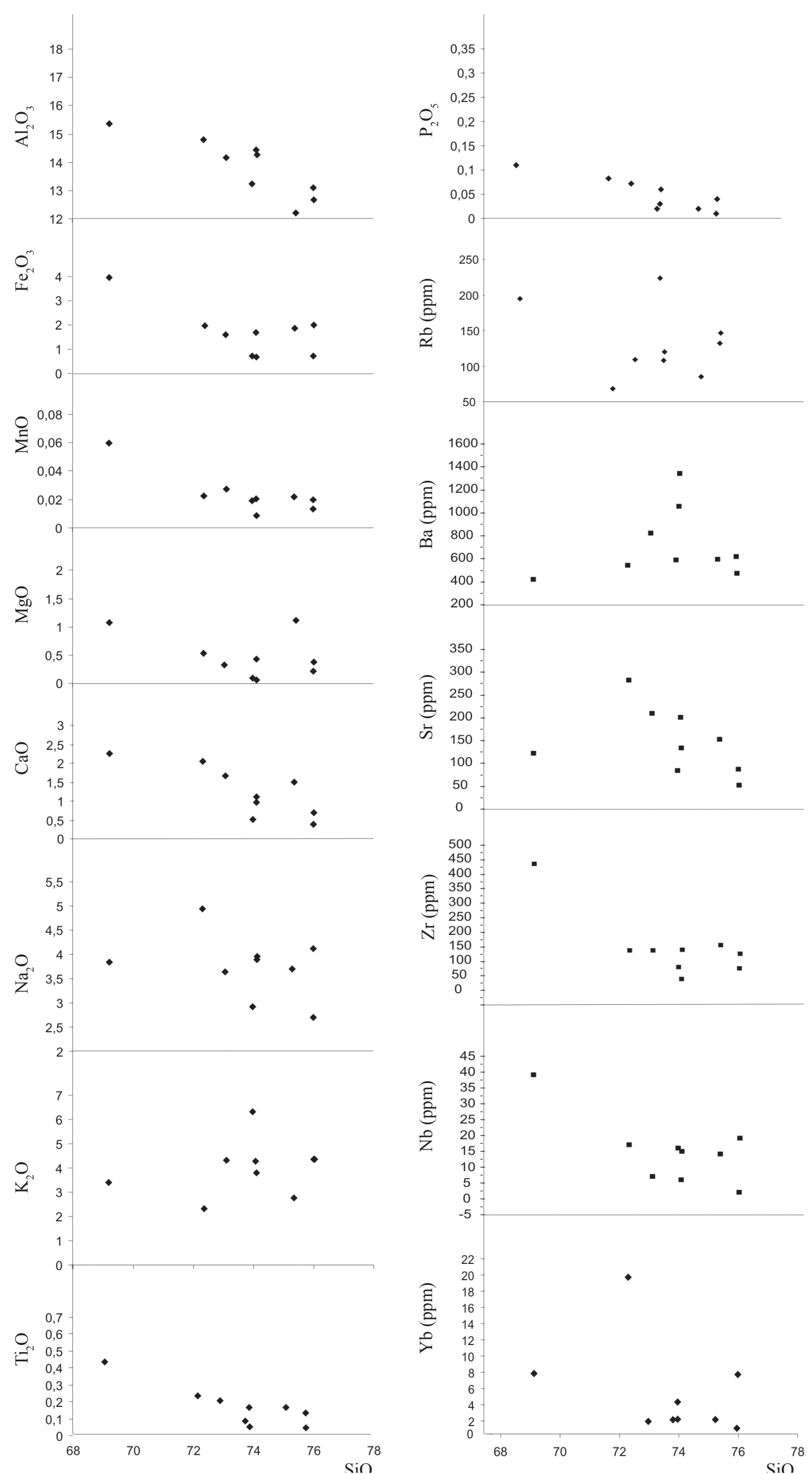

Figura 11 - Diagramas de variação tipo Harker para amostras do Metagranitoide Grão Mogol. 

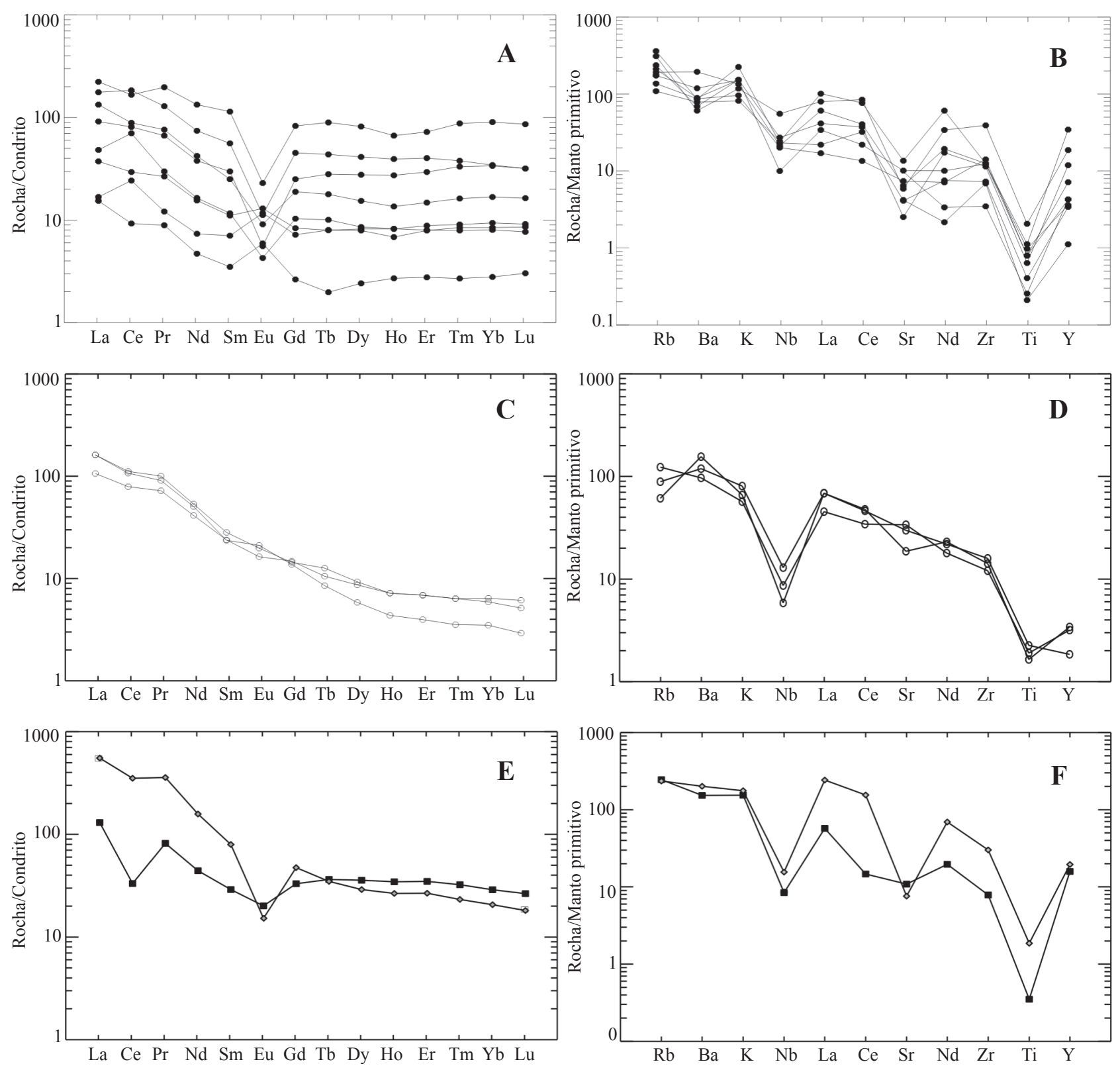

Figura 12 - Distribuição dos elementos terras raras normalizados para condrito (Boyton 1984) e diagramas multielementais normalizado pela abundância no manto primitivo (McDonnough et al. 1992) em amostras dos granitoides intrusivos no Complexo Campos Gerais. (A e B) Metagranitoide Grão Mogol; (C e D) Metatonalito; (E e F) Granitos Itapixé (circulo aberto) e Córrego do Sapateiro (quadrado preenchido).

Gerais pode indicar a não retenção de grandes quantidades de plagioclásio na fonte. Ao contrário, presença desta anomalia no Ortognaisse Mandembo sugere a retenção deste mineral na fonte ou o seu fracionamento no processo de diferenciação magmática. Geralmente a ausência de anomalias negativas de Eu está relacionada ao aumento da fugacidade de $\mathrm{O}_{2}$ no sistema (Wilson 1989). O Eu normalmente possui valência 3+, como a maioria dos ETR. No entanto, em condições com baixa fugacidade de oxigênio, a valência do $\mathrm{Eu}$ se torna $2+$, fazendo com que seu raio iônico aumente e que ele passe a ter comportamento semelhante ao do Sr, substituindo o cálcio na estrutura do plagioclásio. A presença de condições com alta fugacidade de oxigênio causaria a prevalência de $\mathrm{Eu}^{3+}$, diminuindo o seu raio iônico, dificultando sua retenção em plagioclásio.

Assim, os magmas geradores dos protólitos do Ortognaisse Campos Gerais parecem possuir uma estreita relação com fusão de granada anfibolito ou hornblenda eclogito, seguido pela contaminação em ETR leves e LILE oriundos da crosta oceânica em subducção ou de contaminação crustal . Dentre os parâmetros 
químicos utilizados para a definição de terrenos TTG destacam-se (Smithies 2000; Martin et al. 2005): $\mathrm{SiO}_{2}$ $\sim 70 \% ; \mathrm{Al}_{2} \mathrm{O} 3>15 \%$; $\mathrm{Yb}<1 \mathrm{ppm} ; \mathrm{La} / \mathrm{Yb}>30$ (geralmente); $\mathrm{Na}_{2} \mathrm{O} / \mathrm{K}_{2} \mathrm{O}>1$; $\mathrm{Sr}$ e $\mathrm{Ba}>500$ ppm. Estas condições foram relativamente atendidas para o conjunto, salvo raras exceções nos teores de $\mathrm{Ba}, \mathrm{Sr}, \mathrm{e} \mathrm{Yb}$ encontrados em algumas amostras. Pare o Ortognaisse Mandembo, o enriquecimento em ETR leves, o fracionamento em ETR médios e a presença de anomalias de Eu parecem sugerir uma linhagem genética de magmas gerados por fusão de rocha contendo no resíduo plagioclásio e hornblenda. A conformação deste ortognaisse como uma série de alto $\mathrm{K}_{2} \mathrm{O}$, a torna similar às suítes de alto potássio do Arqueano Superior (De Wit 1998). Assim, a fusão discreta de crosta TTG catazonal, seguida do enriquecimento em LILE parece ser uma possibilidade para a geração destas rochas, o que explicaria o padrão observado em ETR, a razão $(\mathrm{La} / \mathrm{Yb}) \mathrm{N}$ e as anomalias de Eu.

O empobrecimento dos magmas geradores dos protólitos dos gnaisses em $\mathrm{Ni}, \mathrm{Cr}$ e $\mathrm{Mg}$, pode ser um indicativo de que o manto litosférico ou astenosférico metassomatizado não participou substancialmente na magmatogênese. Valores de $\mathrm{Ni}, \mathrm{Cr}$ e Mg elevados são comuns apenas em granitoides do Arqueano superior, como os sanukitoides (100 ppm, 100 ppm e \#Mg > 0,62) (Lopez, Castro, Fernandez 2006), formados essencialmente por fusão parcial da cunha mantélica e mistura com material vindo da litosfera oceânica em subducção. No Ortognaisse Campos Gerais, mesmo os membros mais primitivos apresentam valores de $\mathrm{Ni}$, $\mathrm{Cr}$ e \#Mg inferiores às médias dos sanukitoides.

Anomalias negativas de $\mathrm{Nb}$ e Ti observadas nos diagramas multielementais indicam retenção de óxido de titânio, possivelmente rutilo, ilmenita e/ou hornblenda na fonte. Outra possibilidade é a presença de uma fonte originalmente empobrecida nestes minerais ou mesmo nestes elementos. A baixa correlação para $\mathrm{Na}_{2} \mathrm{O}, \mathrm{K}_{2} \mathrm{O}$ e Ba no Ortognaisse Campos Gerais e de $\mathrm{K}_{2} \mathrm{O}, \mathrm{Rb}$ e $\mathrm{Ba}$ no Ortognaisse Mandembo, parecem indicar algum processo que modifica a composição e a quantidade de feldspatos alcalinos nos sistema magmático, como assimilação crustal próxima à temperatura do mínimo granítico. Outra possibilidade é a remobilização destes elementos durante o metamorfismo regional. A dispersão observada para $\mathrm{Zr}$ pode ser indicativa de assimilação de xenocristais de zircão e outras fases acessórias da encaixante, o que em parte comprovaria a assimilação de crosta continental.

No Metagranitoide Grão Mogol, o padrão encontrado para a distribuição de ETR normalizados pela abundância em condrito mostrou ser idêntico àquele da média dos granitoides de margem continental ativa pós 2,5 Ga (Martin 1994). No entanto, os baixos teores em $\mathrm{Cr}$, Ni e \#Mg, comparados àqueles de granitoides arqueanos formados em parte por fusão de cunha mantélica, como sanukitoides (Martin et al. 2005), deixam dúvidas em relação a esta fonte na participação da geração dos magmas dos protólitos. Os padrões observados para ETR leves mostram um leve enriquecimento de todo o grupo, o que evidencia contaminação por materiais crustais ou fluidos oriundos de litosfera oceânica. O padrão observado para os ETR pesados indica uma fonte sem granada ou hornblenda e com plagioclásio (anomalias negativas de $\mathrm{Sr}$ e Eu). Nos diagramas multielementais normalizados pelo manto primitivo, as anomalias negativas de $\mathrm{Nb}$ podem indicar fonte magmática empobrecida, como basaltos toleíti$\cos$ ou correspondentes metamorfisados. Anomalias negativas de Sr a Ti indicam fracionamento de plagioclásio e óxido de titânio, respectivamente, estando em conformidade com o comportamento de $\mathrm{CaO}$ e $\mathrm{TiO}_{2}$ observados nos diagramas tipo Harker. $\mathrm{O}$ enriquecimento em $\mathrm{K}_{2} \mathrm{O}$ e ETR leves pode ser indicativo da fusão parcial de uma crosta continental do tipo TTG na gênese dos protólitos deste granitoide, à maneira das séries de alto $\mathrm{K}_{2} \mathrm{O}$ (De Wit 1998).

Nos metatonalitos a distribuição de ETR mostrou a ausência de anomalias negativas de Eu e um forte fracionamento de ETR pesados, o que indica a ausência de plagioclásio na fonte e a presença de um resíduo constituído por granada, corroborando para a fusão de eclogito ou granada-anfibolito como rocha fonte destes magmas. Nos diagramas multielementais, o formato da curva mostrou grande similaridade com as curvas descritas por Martin et al. (2005) para terrenos TTG. A ausência de anomalias negativas de Sr exclui a participação de plagioclásio no resíduo da fusão e a forte anomalia negativa de $\mathrm{Nb}$ demonstra uma fonte oriunda de manto empobrecido, possivelmente MORB ou seus equivalentes metamorfisados. Os valores $\varepsilon N d$ próximos a zero ou levemente negativos comprovam a origem a partir de rochas de afinidade a MORB. Os parâmetros químicos utilizados para a definição de terrenos TTG $\left(\mathrm{SiO}_{2} \sim 70 \%\right.$; $\mathrm{Al}_{2} \mathrm{O}_{3}>15 \% ; \mathrm{Yb}<1 \mathrm{ppm} ; \mathrm{La} / \mathrm{Yb}>30 ; \mathrm{Na}_{2} \mathrm{O} / \mathrm{K}_{2} \mathrm{O}>$ 1; $\mathrm{Sr}$ e $\mathrm{Ba}>500 \mathrm{ppm}$ ), indicam forte similaridade dos metatonalitos com estas rochas.

O Granito Córrego do Sapateiro exibe na distribuição dos ETR uma leve anomalia de Eu e ETR pesados não fracionados, o que indica uma fonte com plagioclásio, sem granada e hornblenda. $\mathrm{O}$ enriquecimento 
em ETR leves e o caráter peraluminoso de alto-K sugerem participação crustal no processo magmático. $\mathrm{O}$ fracionamento relativamente baixo de ETR leves em relação aos ETR pesados e a baixa razão $\mathrm{La} / \mathrm{Yb}$ podem ser um indício de que o magma parental de uma provável série formadora deste granito possuía afinidade TTG. Apesar de baixa concentração de Ni, $\mathrm{Cr}$ e $\mathrm{Mg}$, a semelhança dos ortognaisses e metatonalitos, a fusão de manto é um processo que não pode ser descartado na gênese de seu magma progenitor. Por se tratar de um membro ácido e evoluído de uma possível suíte originada a partir de fusão de cunha mantélica, é esperado que essa rocha seja empobrecida nestes elementos. O caráter de alto-K desta rocha pode estar relacionado ao metassomatismo da cunha mantélica e assimilação crustal.

No Granito Itapixé, a forte anomalia de Eu e o leve fracionamento de ETR pesados indicam fonte retendo plagioclásio e alguma hornblenda e/ou granada, possivelmente um anfibolito. O enriquecimento em ETR leves e o caráter peraluminoso de alto-K sugerem sua origem a partir de anatexia de crosta inferior máfica, possivelmente por fusão adiabática em ambiente sin a tardi colisional, com posterior assimilação de LILE em mesozona e epizona.

AGRADECIMENTOSOs autores agradecem à Dra. Beatriz Paschoal Duarte (TEKTOS) e aos Drs. Ciro Alexandre Ávila e Ruben Porto Júnior pelos comentários e discussões a respeito da geologia da área de estudo e dos dados obtidos. Ao Professor Dr. Fábio Pentagna Paciullo (in memoriam) pelo acompanhamento em campo e discussões sobre a geologia local. Aos Drs. Artur Corval e Janaína Lobo sobre discussões a respeito dos aspectos geoquímicos do traba1ho. A Fundação de Amparo à Pesquisa do Estado do Rio de Janeiro (FAPERJ) pelo apoio financeiro.

\section{Referências}

Alkmim F.F. 2004. O que faz de um cráton um cráton? O Cráton do São Francisco e as Revelações Almeidianas ao delimitá-lo. In: Mantesso-Neto V., Bartorelli A., Carneiro C.D.R., Brito-Neves B.B. (eds). Geologia do Continente Sul-Americano: evolução e obra de Fernando Flávio de Almeida. São Paulo, Beca.

Alkmim F.F. \& Marshak S. 1998. Transamazonian Orogeny in the southern São Francisco Craton Region, Minas Gerais, Brazil: evidence for Paleoproterozoic collision and collapse in the Quadrilátero Ferrífero. Precambrian Research, 90:29-58.

Barker F. \& Arth J.G.1976. Generation of trondhjemitictonalitic liquids and Archean bimodal trondhjemitic basalt suites. Geology, 4:596-600.

Boyton W.V. 1984. Geochemistry of the rare earth elements: meteorite studies. In: Henderson P. (ed.). Rare earth element geochemistry. Elsevier, p. 63-114.

Campos J.C.S., Carneiro M.A., Basei M.A.S. 2003. U-Pb evidence for late Neoarquean crustal reworking in the southern São Francisco Craton (Minas Gerais, Brazil). Anais da Academia Brasileira de Ciências, 75(4):497511.

Carneiro M.A., Jordt-Evangelista H., Teixeira W. 1997. Eventos magmáticos de arqueanos de natureza calcialcalina e tholeítica no Quadrilátero Ferrífero e suas implicações tectônicas. Revista Brasileira de Geociências, 27(1):121-128.

Carvalho S.G., Soares P.C., Antônio M.C., Zanardo A., Oliveira M.A.F. 1993. Geologia da sequência vulcanosedimentar de Alpinópolis. Revista Brasileira de Geociências, 23(1):38-51.

Cavalcante J.C., Cunha H.C.S., Chieregati L.A., Kaefer L.Q., Rocha J.M., Daitx E.C., et al. 1979. Projeto Sapucaí, estado de São Paulo, Rio de Janeiro e Minas Gerais. Brasília, DNPM/CPRM, Relatório Final de Geologia, 229 p.

Corrêa da Costa P.C. 1999. Episódios de formação de crosta continental arqueana no Cráton do São Francisco Meridional: Um exemplo a partir da região de Candeias, Campo Belo, MG. Dissertação de Mestrado, Departamento de Geociências, Universidade Federal de Ouro Preto, Ouro Preto, 132 p.

Crosta A.P., Choudhuri A., Szabó G.A.J., Schrank A. 1986. Relações entre tipos litológicos e suas estruturas regionais nos terrenos arqueanos e paleoproterozóicos do sudoeste de Minas Gerais. In: SBG, Congresso Brasileiro de Geologia, 34 ,Goiânia, Anais, 2:710-721.

De La Roche H., Leterrier J., Grande Claude P., Marchal M. 1980. A classification of volcanic and plutonic rocks using R1-R2 diagrams and major elements analyses its relationships and current nomenclature. Chemical Geology, 29:183-210.

De Wit M.J. 1998. On Archean granites, greenstones, cratons and tectonics: does the evidence demand a verdict? Precambrian Research, 91(1):181-226.

Fernandes R.A. 2001. Etapas de formação de crosta continental (do Mesoarqueano ao Mesoproterozóico) no Cráton do São Francisco Meridional. Dissertação de Mestrado, Departamento de Geociências, Universidade Federal de Ouro Preto, Ouro Preto, 128 p.

Irvine T.N. \& Baragar W.R.A. 1971. A guide to the chemical classification of the common volcanic rocks. Canadian Journal of Earth Sciences, 8(5):523-548.

Lê Maitre R.W. 1989. A Classiflcation of Igneous Rocks and Glossary of Terms. Recommendation of the IUGS Subcommission on Systematic of Igneous Rocks. Blackwell, Oxford, 193 p. 
Lopez S., Castro A., Fernandez C. 2006. Evolution of the Archean continental crust. Insights from the experimental study of archaean granitoids. Geophysical Research Abstracts, 7:115-117.

Maniar P.D. \& Piccoli P.M. 1989. Tectonic discrimination of granitoids. Bulletin Geological Society of America, 101:635-643.

Martin H., Smithies R.H., Rapp R., Moyen J.F., Champion D. 2005. An overview of adakite, tonalite-trondhjemitegranodiorite (TTG), and sanukitoid: relationships and some implications for crustal evolution. Lithos, 79:1-24.

Martin H. 1994. The Archean grey gneisses and the genesis of continental crust. In: Condie K.C. (ed), Archean crustal evolution. Amsterdam, Elsevier, 542 p.

McDonough W.F., Sun S., Ringwood A.E., Jagoutz E., Hofmann A.W. 1992. Potassium, Rubidium and Cesium in the Earth and Moon and the evolution of the mantle of the Earth. Geochimica et Chosmochimica Acta, 56(3):1001-1012.

Morales A.W.N. \& Hasui Y. 1993. Evolução tectônica da porção ocidental do Cinturão de Cisalhamento Campo do Meio. In: SBG, Simpósio Nacional de Estudos Tectônicos - SNET, 4º , Belo Horizonte, Anais, 12:292-296.

Noce C.M., Machado N., Teixeira W. 1998. U-Pb geocronology of gneisses and granitoids in the Quadrilátero Ferrífero (southern São Francisco Craton): ages constrains for Archean and Paleoproterozoic magmatism and metamorphism. Revista Brasileira de Geociências, 28:95-102.

O'Connor J.T. 1965. A classification of quartz-rich igneous rocks based on feldspar ratios. United States Geological Survey Professional Paper, (525-B):9-84.

Quéméneur J.J.G. \& Noce C.M. 2000. Geochemistry and petrology of felsic and mafic suites related to the paleoproterozoic Transamazonian Orogeny In Minas Gerais, Brazil. Revista Brasileira de Geociências, 30:87-90.

Roig H. L. \& Schrank A. 1992. Caracterização da zona de sutura Jacuí-Conceição da Aparecida - limite norte do complexo de nappes de Guaxupé- MG. In: SBG, Congresso Brasileiro de Geologia, $37^{\circ}$, São Paulo, Anais, 283-285.

Smithies R.H. 2000. The Archaean tonalite-trondhjemitegranodiorite (TTG) series is not an analogue of Cenozoic adakite. Earth and Planetary Science Letters, 182(1):115-125.

Szabó G.A.J., Roig H.L., Schrank A., Choudhuri A. 1993. Duas faixas lito-estruturais distintas e o limite das Províncias Tocantins e Mantiqueira, entre Alpinóplis e Nova Resende. In: SBG, Simpósio sobre o Cráton do São Francisco e suas faixas marginais, II, Salvador, Anais, 272-274.

Szabó G.A.J. 1992. Compartimentação do Complexo Campos Gerais entre Carmo do Rio Claro e Fortaleza de Minas, MG. Boletim do Instituto de Geociências/USP, 129-130.

Szabó G.A.J. 1989. Contexto geológico e petrologia das rochas metaultramáficas de Alpinópolis, MG. Dissertação de Mestrado, Instituto de Geociências, Universidade de São Paulo, São Paulo, 203 p.

Teixeira W., Cordani U.G., Nutman A.P., Sato K. 1998. Polyphase Archean evolution in the Campo Belo Metamorphic Complex, southern São Francisco Craton, Brazil: SHRIMP U-Pb zircon evidence. Journal of South American Earth Sciences, 11(3):279-289.

Teixeira W., Akimoto H., Siga Jr. O., Sato K. 1989. A evolução geocronológica dos terrenos granítico-gnáissicomigmatíticos ao sul da Faixa Canastra, sudoeste de Minas Gerais. In: SBG, Simpósio de Geologia de Minas Gerais, $5^{\circ}$, Belo Horizonte, Anais, 10:243-246.

Teixeira W., Cordani U.G., Kawashita K., Taylor P.N., Van Schmus W.R. 1987. Archean and early Proterozoic crustal evolution in the southern part of the São Francisco Craton. In: International Symposium on Granite and Associated Mineralizations - Extended Abstracts, Salvador, 1:37-40.

Teixeira W., Sabaté P., Barbosa J., Noce C.M., Carneiro M.A. 2000. Archean and paleoproterozoic tectonic evolution of the São Francisco Craton, Brazil. In: Cordani U.C., Milani E.J., Thomaz Filho A., Campos D.A. (ed.). Tectonic Evolution of South America. CPRM, Rio de Janeiro, 855p.

Thompson R.N., Morrison M.A., Hendry G.L., Parry S.J. 1984. An assessment of the relative roles of crust and mantle in magma genesis: an elemental approach. Philosophical Transactions of the Royal Society of London, 310:549-590.

Turbay C.V.G., Valeriano C.M., Rossi A., Rocha e Silva V.G.M. 2008. Geologia do Complexo Campos Gerais ao sul de Alpinópolis, sudoeste de Minas Gerais. Geonomos, 16(2):79-90.

Turbay C.V.G. 2010. Caracterização petrológica e geocronológica do Complexo Campos Gerais (Arqueano), Minas Gerais, Brasil. Tese de doutorado, Faculdade de Geologia, Universidade do Estado do Rio de Janeiro, Rio de Janeiro, $176 \mathrm{p}$.

Valeriano C.M., Simonetti A., Turbay C., Rossi A.,Nogueira J.R. 2006. U-Pb zircon ages by LA-MCICPMS from orthogneisses south of Alpinópolis (Minas Gerais, SEBrazil): reconstructing Paleoproterozoic cratons on the southwestern margin of the São Francisco paleocontinent. GAC/MAC Annual Meeting, Montreal.

Winchester J.A. \& Floyd P.A. 1977.Geochemical discrimination of different magma series and their differentiation products using immobile elements. Chemical Geology, 20:325-343.

Wilson M. 1989. Igneous petrogenesis: a global tectonic approach. London, Unwin Hyman ed. 466p.

Zanardo A., Morales N., Carvalho S.G., Simões L.S.A., Oliveira M.A.F. 1990. Evolução metamórfica da porção sul do Cráton do São Francisco. In: SBG, Congresso Brasileiro de Geologia, 36º, Natal, Anais, 1945-1955.

Manuscrito ID 21474

Recebido em: 06/05/2011 Aprovado em: 22/06/2012 